\title{
En busca del tiempo homérico con la mirada y la palabra de Antonio Prieto (lectura de El ciego de Quíos)
}

\author{
Concepción NÚÑ̃Z REY \\ Universidad Complutense \\ cnunezre@ucm.es
}

\author{
"Laertíada de linaje de dioses, \\ Odiseo fecundo en recursos”.
}

\begin{abstract}
RESUMEN
En El ciego de Quíos, el novelista Antonio Prieto inventa la vida de Homero alimentándola con figuras y hechos procedentes de la Ilíada y, sobre todo, de la Odisea. El relato se enriquece con el conocimiento histórico en torno a los dos grandes poemas, y lo enmarca un amplio despliegue mitológico. Más allá, la novela alcanza un significado trascendente. Descubrimos como motor narrativo el esfuerzo homérico por vencer la fugacidad humana mediante la escritura, lo que crea un vínculo atemporal con el propio anhelo de nuestro autor; así, la novela nos ofrece un ejemplo máximo del fenómeno bautizado como fusión mítica por Antonio Prieto.
\end{abstract}

Palabras clave: Homero, Ilíada, Odisea, Nausícaa, mitología, mirada, escritura, fusión mítica.

\begin{abstract}
In The blind person of Quíos, the novelist Antonio Prieto invents Homero's life feeding it with figures and facts from the Ilíada and, especially, from the Odyssey. The story is enriched by the historical knowledge about these great poems, and is framed in a rich mythological context. Beyond this, the novel reaches a transcendent meaning. We discover as narrative engine the Homeric effort to overcome the human fleetingness by means of the writing, thus creating a timeless link with the own longing of our author; this way, the novel offers us a maximum example of what Antonio Prieto termed as mythical fusion.
\end{abstract}

Key words: Homero, Ilíada, Odyssey, Nausícaa, mythology, the look, the writing, mythical fusion 
SUMARIO: 1 . La lectura y la vida; 2 . Un relato real e imaginario; 3. Una vida humana creada y ordenada por su propia obra; 4. Hacia La Cabaña-Parnaso; 5. Peregrino-Homero; 6. Peregrino-Odiseo, y el coro de personajes; 7. Todas y una: Euriclea, Nausícaa, Ifigenia, Eurícide, Helena, Yanira; 8. El incesante meditar del peregrino; 9. La mirada, la palabra, la escritura; 10. Las emociones sensoriales; 11. Las modulaciones de la voz. Un universo en rotación; 12. El encuentro en la escritura.

\section{La lectura y la vida}

El lector atento de una obra literaria descubre con frecuencia un mundo que le era desconocido, y solo en alguna ocasión vive un proceso más íntimo en que identifica lo descubierto ahora como algo que ya formaba parte de sí mismo, aunque ha adquirido una dimensión nueva tras la reciente experiencia lectora. Se alimenta así un anhelo que guardábamos latente, de igual modo que nos sucede a veces frente a la realidad, como cuando Antonio Machado descubre, al contemplar los álamos del Duero en Soria: "me habéis llegado al alma, / ¿O acaso estabais en el fondo de ella?”.

Así podrá suceder a muchos lectores de El ciego de Quíos, la novela de Antonio Prieto, si esos lectores se han sentido atraídos previamente por el mundo heroico y fabuloso transmitido en la Ilíada y la Odisea, los dos grandes poemas homéricos que son el punto de partida de la memoria histórica y cultural de Occidente ${ }^{1}$.

A lo largo del tiempo, los grandes modelos literarios son imitados, pero solo en ocasiones son reinterpretados, recreados, incorporando una nueva forma de mirar que da lugar a una nueva obra fundamental. Lo más frecuente es hacer viajar al presente los elementos clave del modelo antiguo para poder interpretar las nuevas realidades, pero mucho menos frecuente es que un autor viaje al pasado en que nació una gran obra, como hace Prieto, para reinterpretarla desde la perspectiva del presente, un presente que tiene el privilegio de conocer y recoger todo lo superpuesto en el transcurso del tiempo.

Vemos nacer así una extraordinaria hazaña, solo posible en el seno de la literatura, la de conectar el pensar y el sentir entre hombres de tiempos muy distantes, sorteando el inmenso vacío que los separa. Es literatura navegando por el tiempo en busca de otra literatura y fundiéndose con ella. De tal hazaña como autor, Antonio Prieto nos convierte en testigos como lectores ${ }^{2}$.

1 El impulso inicial del presente trabajo era bucear en El ciego de Quíos para hallar los frutos de una lectura atenta, aunque desprevenida. Ineludiblemente, el enorme interés que la novela, y toda la obra de Antonio Prieto, ha provocado en muy prestigiosos especialistas hará preciso recoger siquiera su eco en estas páginas.

${ }^{2}$ Así lo explica el autor en su muy conocido ensayo sobre el concepto de fusión mítica: "son dos tiempos (no importa la distancia cronológica) que se funden en un nuevo tiempo: en una atemporalidad que salva toda cronología” (A. Prieto (1972), p.140). 
Como es natural, tan ambicioso experimento presenta una gran complejidad: complejos son los materiales que construyen la novela por la diversidad de su origen y más compleja aún es la composición del relato en que son ordenados para la reconstrucción o recreación de un tiempo lejano. Desentrañar y ordenar el mundo de la novela requiere encontrar un centro desde el que avanzar enlazando sus diversos ingredientes. Buscándolo, percibimos la fascinación del autor por el pasado, sea con el rigor de los datos históricos o con los frutos nacidos de la imaginación humana ${ }^{3}$. Y en ese pasado, necesariamente, ocupa un lugar cenital el mítico mundo homérico, el de los orígenes, el primigenio, el que ha alimentado sin cesar el espíritu humano de todas las edades como ingrediente imprescindible de su educación. Un verdadero hilo conductor de la imaginación de los hombres que no ha perdido jamás su prestigio ${ }^{4}$.

Como es natural, la inmensa masa de hombres tan distintos y distantes, dio lugar a muchos niveles de lectura; entre posibilidades infinitas, para algunos, lo leído viene a formar parte de sí mismos para siempre. En ese extremo viene a situarse Antonio Prieto, quien leyó los poemas hasta el nivel más escondido, rastreando todos sus significados, y buscando además todo el conocimiento arqueológico y erudito posterior ${ }^{5}$, que ha venido a iluminar muchas incógnitas del tiempo histórico en el que nacieron.

Por otra parte, en los grandes poemas que llamamos homéricos se han inspirado sin cesar las más dispares obras artísticas, en especial, como es lógico, innumerables obras literarias, algunas de ellas reconocidas como magistrales (baste recordar Ulises de Joyce $)^{6}$. En general, los diversos autores han tomado prestados elementos de los poemas, en mayor o menor medida, para incorporarlos al presente de su propia obra.

En El ciego de Quíos, Antonio Prieto invierte el proceso y emprende un viaje a aquel lejano tiempo mítico y literario para instalarse en él con todo su bagaje de conocimientos, abarcando la emoción nacida de los poemas y todo lo conocido y desconocido en torno a su creación y a las circunstancias históricas que la envolvieron. Pero el estudio erudito dejaba muchos misterios sin resolver. Así nació su proyecto novelesco, como un deseo del autor de completar con la imaginación, siguiendo el entramado de pistas, el complejo proceso que hizo nacer los poemas

3 “detrás de cada palabra, oral o escrita, de Antonio Prieto está el hombre enamorado de la vida y la literatura [...] en atemporal diálogo secreto con sus amigos clásicos y modernos, el humanista, en fin” (Á. García Galiano (1996), p. 111).

${ }^{4}$ Teresa Hernández (1996) señala el propósito del autor: "reivindicar la condición modélica, insuperable y eterna de la obra de Homero, del texto de los textos”.

${ }^{5}$ Ramón Hernández (1996) advierte: "Recrea el mito homérico a través de una evocación erudita que elude los peligros del didactismo”.

6 Esa presencia ha sido objeto de grandes estudios, como los de Piero Boitani o William B. Stanford. En España, recordemos la huella homérica en Cunqueiro, Martín Santos, etc. 
trascendentales, como si intentase redibujar un viejo mapa del que solo conservase fragmentos dispersos.

Pero imaginar implica inevitablemente la proyección de uno mismo, y Antonio Prieto se lanzó a esta aventura literaria con una entrega total; por una parte, construyendo el entramado del nuevo relato a partir de una precisa erudición, fruto de su riguroso conocimiento de la cultura clásica, como corresponde a un verdadero humanista; y por otra, incorporando, como el bordado sobre una trama, su propio pensar y sentir, su vivir como hombre, sus anhelos $\mathrm{y}$, levemente, algunas experiencias propias ${ }^{7}$. Se trata así de que el autor recrea un mundo conocido librescamente, haciéndolo vivir de nuevo con su propia forma de mirar. ${ }^{8}$

Según hemos de ver, todas las claves de su plan literario irán siendo explicadas en la misma obra a través del autor protagonista.

\section{Un relato real e imaginario}

Imitando a Antonio Prieto en su propia expresión, se propuso "seguir el camino" de los poemas hasta sus orígenes, y en ellos buscó, como es lógico, al autor que los compuso. No pudo conformarse con el nombre de Homero, dudoso para los estudiosos y tal vez inexistente, pero no podía dudar que existió aun sin nombre (asunto tratado en la novela, al que volveremos) y que hubo de viajar y conocer tierras y hombres, como hacían los aedos para difundir sus cantos. Así que decidió nombrarlo con un genérico, el Peregrino, y se propuso construir todo el relato en torno a la que pudo ser su trayectoria vital, como hombre y como escritor, descubriéndolo e interpretándolo a través de las claves halladas en sus propios poemas $^{9}$.

En su sagaz lectura, Antonio Prieto se planteó como nuevo enigma de dónde procedían algunos personajes que aparecían, sobre todo en la Odisea, conmoviéndonos con su sentir humano y conviviendo en los poemas con los belicosos héroes cuyas hazañas admiramos, rodeados además de dioses mitológicos y seres fabulosos. De dónde procedían las peripecias y los sufrimientos que ha de

${ }^{7}$ Prieto nos hace "sentir la intensidad de unos autores que él ha sabido recuperar y revitalizar, desdibujando las fronteras entre academicismo y ficción narrativa, por no hablar de autobiografía” (E. Gómez Ramos (1997), p. 15).

${ }^{8}$ Estas impresiones nacidas de nuestra lectura vienen al encuentro del ya mencionado concepto de fusión mítica, elaborado y vertido por el autor mucho antes de la creación de esta novela, indicando las posibles vías de fusión: “Tenemos así tres cauces de fusión mítica: a) con un argumento mítico, b) con un personaje mítico y c) con un personaje real al que la historia o la leyenda le han concedido la atemporalidad del mito” (A. Prieto (1972), p. 142).

9 "Prieto sigue (conscientemente) la pauta de las biografías antiguas de los poetas, al plantear una reconstrucción biográfica desde la propia obra creada” (E. Suárez de la Torre (2008), p. 559). 
soportar Odiseo, tan reconocible, revestido de los atributos y valores de los demás hombres y sometido a los azares de la existencia, como "un hombre nuevo", distinto de los legendarios guerreros predominantes en la Ilíada. Y de dónde procedían Nausícaa, o Euriclea, o Alcínoo, o Eumeo, o algunos otros creados por el nominado "Homero".

Así, la imaginación de Antonio Prieto pudo generar la hipótesis de que estuvieran inspirados en los personajes reales que acompañaron la vida del desconocido autor, a los que este quiso inmortalizar en sus versos junto a los héroes del pasado. Sobre esta invención, construyó su complejo experimento narrativo; extrajo de los poemas a estos personajes imaginarios para situarlos junto al autor que los creó y hacerlos vivir junto a él en el argumento de su propia novela. Pero Prieto nos sorprende al mismo tiempo dando un paso más, afirmando que fueron seres tan reales e históricos como el propio autor y que en efecto fueron llevados por este al mundo imaginario de sus poemas. Y aún se superpone algo más: al inventar al Peregrino, Antonio Prieto crea la posibilidad de representarse en él, de convertirlo en un alter ego para depositar su propio universo mental y emocional, y para compartir con él las ideas sobre la creación literaria ${ }^{10}$.

Paso a paso hemos de recorrer y deslindar el precioso entramado de elementos que pueblan la novela, pero se hace preciso antes que nada condensar la peripecia en que se insertan, la que fluye a lo largo de la imaginaria vida del Peregrino.

\section{Una vida humana creada y ordenada por su propia obra}

Inventar la vida de Homero (o el peregrino) no consistió para Antonio Prieto en un espontáneo novelar que jugase libremente con la información acumulada. Fue un reto de enorme dimensión: primeramente, por tratarse, bajo cualquier nombre, del autor de autores, el primero, el que nos da la distancia de nuestro pasado, al que todos hubieron y habrán de referirse mientras se conserve la memoria de nosotros mismos, de nuestro imaginario como europeos. Pero Homero es sus poemas, y su vida ha de estar ligada al hecho extraordinario de haberlos creado, de modo que Antonio Prieto se propuso reconstruirla inventando el proceso que condujo a esa creación. Por tal razón, su novela sigue un plan ordenado con rigor y estructurado en dos partes correspondientes a los dos poemas, que a su vez les sirven de título: "Ilio", la primera, relata la vida del peregrino desde su juventud en Quíos hasta casi la vejez, con una enorme elipsis de la mayor parte de su tiempo, y culmina en Éfeso cuando comienza a escribir la Ilíada. Bajo el título de "Odisea" se abre la segunda parte, cuando el peregrino regresa a Quíos convertido en aedo, y prosigue su viaje recitando episodios de las aventuras de Odiseo, para refugiarse por fin, ya viejo y casi ciego, en la isla de Íos, donde inicia la escritura de la Odisea al final de la

\footnotetext{
10 "Prieto buceará en su acervo cultural para, muy europeamente, resucitar y utilizar un viejo procedimiento de sabor humanista: el mito” (Palomo (1967), p. 728).
} 
novela. Esta equilibrada distribución de la narración se completa aún con la subdivisión de cada parte en cinco capítulos; podríamos decir que la materia del relato es sometida por su autor a un orden perfecto, armonioso y racional, respetuoso del ideal clásico.

Construido el edificio de su novela, aún lo inserta el autor en un nuevo marco: le antepone como prólogo un "Prospecto" y le añade como epílogo una "Coda", en los cuales traslada su relato y a su "peregrino" a una realidad imaginaria e ideal, el mundo del arte, de la Literatura, de las musas, de los artistas, que si se podría simbolizar en el monte Parnaso, Antonio Prieto lo transforma en una cabaña del monte donde habitan unas bellas damas atemporales, equiparables a las musas. Allí acogen a todos aquellos que se elevan de la realidad del mundo histórico y acuden a refugiarse junto a ellas para establecer un diálogo incesante acerca de los grandes temas del espíritu humano. Todo ello en fin, símbolo del espacio espiritual de la literatura que acoge a hombres de distintas procedencias para un diálogo que vence los límites del espacio y del tiempo ${ }^{11}$.

Pero volvamos al argumento que sigue la novela para intentar condensarlo y poder abrir desde ese armazón las vías y los puentes que conectan con otras perspectivas de la narración.

En su edad más joven, el peregrino crece en la isla de Quíos, fascinado con las historias de los lejanos héroes de Troya que relatan los aedos en la plaza pública. Allí escucha sobre todo al anciano Aristocles, convertido en el maestro con quien dialoga, igual que lo hace con el antiguo esclavo Eumeo, quien con sus experiencias corrige los relatos heroicos. También dialoga con su propio padre, el noble Alcínoo, quien acumuló conocimiento en sus largos viajes como pescador. Unido a su pasión por los relatos orales, el joven ama la escritura, que practica sin cesar y que causa la extrañeza de su madre, la discreta Creteide. Así concibe el gran proyecto de fijar en los signos imperecederos lo que solo ha sido antes fugacidad de la voz.

Surge pronto en el peregrino el deseo de viajar y conocer lugares y hombres para incorporar a su futura escritura las experiencias vividas, no solo las historias escuchadas. Pero sufre una profunda división entre cumplir su anhelo o permanecer junto a Euriclea, hija de Eumeo, cuya belleza ha encendido en él una gran pasión. $\mathrm{Al}$ emprender su viaje, conoce en el barco a Paleneo, quien se convertirá en amigo, en protector y en guía para las experiencias de la vida. Navegan hacia islas como Lesbos, Larisa o Imbros, desde donde divisan Troya; pero muy pronto, en Lemnos, los sueños se desmoronan: el barco es apresado y ambos amigos son reducidos a la

\footnotetext{
11 "El autor sale de su tiempo para protegerse en el tiempo ajeno ya sancionado, en la perennidad del mito; convierte ese tiempo pasado en actualidad, en atemporalidad mítica; así dos tiempos se funden en uno nuevo en el que permanecer; se funde en esa atemporalidad, sintiéndose vida mítica” (M. Hernández Esteban (2002), p. 87).
} 
esclavitud. Pasarán largos años (“infinitos”) encadenados a un remo (tiempo de la gran elipsis narrativa), hasta que en Éfeso, su nuevo amo Lárico le devuelve la libertad cuando conoce su arte como aedo; y el peregrino se dispone a escribir su Ilíada para ofrecérsela antes de ser libre.

La segunda parte se inicia cuando, ya viejo, el peregrino regresa a Quíos, donde solo logra confirmar la desaparición de aquellos que amó, cuya memoria en el lugar está casi perdida. Reemprende su viaje para seguir su destino de aedo recitando en los palacios, pero prefiere relatar las aventuras de Odiseo, con el que se funde a veces y en el que deposita sus largos años de sufrimiento. Algunos episodios de la Odisea son sintetizados como parte de sus recitados, pero otros son protagonizados por el propio peregrino a través del sueño, como la llegada al Hades en busca de los seres queridos; y sobre todo, sorteando el peligro de ser de nuevo esclavizado, el sueño de su huida a una isla remota, que es Feacia, donde fundido con Odiseo se encuentra con Nausícaa, nueva imagen de Euriclea, y con la que al fin vive plenamente su nunca olvidado amor. De nuevo desdoblado de Odiseo, emprende su último viaje, ya anciano y casi ciego, hasta la pequeña isla de Íos, donde se asienta para escribir su Odisea, cuyos primeros hexámetros cierran la novela.

Esta peripecia argumental fluye sin cesar serenamente, como olas suaves que caen sobre la arena, una tras otra. Muy pocas son las acciones narradas, excepto el discurrir de la conciencia del protagonista y su incesante meditar. Las realidades vividas por los personajes son aludidas y apenas descritas, pero engendran un ancho caudal de evocaciones históricas, literarias o mitológicas, que proceden de la erudición de nuestro autor; y más ancho aún es el caudal de reflexiones acerca del sentir del hombre, de sus anhelos, de su propio valor y significado, reflexiones del peregrino en las que vemos transparentarse a nuestro autor. Es necesario por ello, antes de recorrer las distintas vías que abre el relato, adentrarnos en el personaje, ese peregrino Homero que parece ser en el fondo Antonio Prieto.

\section{Hacia La Cabaña-Parnaso}

El autor-narrador Antonio Prieto protagoniza abiertamente, en primera persona, el "Prospecto" y la "Coda" de la novela. Con ellos nos ofrece una verdadera declaración de principios humanos y artísticos que fundamentan su relato, pero no con la exposición abrupta de una tesis, sino con la invención del espacio simbólico y atemporal de La Cabaña. La escogidísima primera frase delimita ya el universo del autor: el "Siempre preferí", y esos "unicornios", esas "veletas de colores colgando de la luna”, o esas “damas de trenzas azules". Es decir, frente a la cerrada realidad ("La historia, como hechos, estaba ya construida", 15) ${ }^{12}$, elige el abierto mundo de la imaginación, de la invención, y La Cabaña viene a ser su ilustración. En ella, como nuevo Parnaso, habitan las cinco hermosas damas portadoras de

\footnotetext{
${ }^{12}$ Las citas de la novela indicarán al final el número de página de su edición.
} 
algunos nombres de las musas (Clío, Euterpe, Polimnia, Calíope), ${ }^{13}$ y a su encuentro acuden sucesivos caballeros ("que parecen desandar el tiempo o remontar la historia”, 10) para dialogar con ellas. Unos son personajes en busca de un autor que los inmortalice (como Alejandro, envidioso de Aquiles por haber tenido a Homero), porque sabían que: "el hombre era, en su misma naturaleza, mirada que necesitaba de unos ojos que lo existieran” (10). Otros caballeros son los propios creadores: así Virgilio, cuya última reflexión será transmitida por una musa a su autor (Hermann Broch) en La muerte de Virgilio, o así Adriano, cuya memoria nos iba a legar Marguerite Yourcenar. Como lo es el dueño de la voz que nos habla, testigo de los sucesos de la Cabaña. En realidad, los vive intensamente por su amor a Ifigenia, única de las cinco damas que no se corresponde con una musa. Tampoco representa aquí su nombre el mito creado por Eurípides, como hija de Agamenón, y recreado por Goethe, ${ }^{14}$ sino que encarna con su belleza a la amada, la mujer ideal, amada que se corresponderá con la Euriclea de la novela y que aún se repetirá en otros nombres, como veremos.

Esta Ifigenia tiene el poder de transformar con su voz lo que escribe el autor, una voz "que caía suavemente como caen los copos de la nieve" (11); con poder incluso de sustituirle y crear su escritura de una forma nueva: "era la voz de Ifigenia la que creaba la palabra y recitaba la vida” (14). De tal modo, el amado personaje, que es ideal de belleza, se convierte en la fuente de la que mana su obra, o mejor, en su propia musa inspiradora.

No solo Ifigenia conecta el mundo de La Cabaña con el de la novela, también conecta ambos mundos el peregrino, quien, disfrazado con un hábito medieval y procedente de sus remotos tiempos, llega a la casa de las musas envuelto en el anonimato; ${ }^{15}$ y es Ifigenia, la musa de nuestro autor, la que, en la Coda final, le hablará del pasado del peregrino, con lo que se anuncia el contenido de la novela que hemos acabado de leer.

Junto a La Cabaña, pero al margen, se sitúa el pueblo, cuya ignorancia alimenta su desconfianza, su temor, e incluso su odio contra ese mundo que no puede comprender, hasta el extremo de desear su destrucción: "millones de personas [...] solo querían vivir la acelerada actualidad” (211). Y también al margen se sitúa el "escribano del Estado" que mide y registra el mundo de La Cabaña, pero que: "Jamás $[. .$.$] comprendería la búsqueda de la belleza que latía en la mirada de la$ escritura, en su deseo de encontrar otra mirada” (213). Así parece simbolizarse el

${ }^{13}$ El autor alude al origen de las musas, desde el Helicón, y a la evolución posterior del mito.

14 Alude al mito y sus modelos, pero su personaje procede de la imagen del cuadro de Timantes El sacrificio de Ifigenia (siglo IV a.C.), y su significado aquí es expresión de la belleza.

${ }^{15} \mathrm{Al}$ presentarlo, alude el autor al abate d'Aubignac, quien impulsó en el siglo XVII la “cuestión homérica”, que negaba su existencia como autor de los poemas. 
mundo que se adueña y comercia con el arte, o mejor, con la literatura, desentendiéndose de su valor y significado y de su perduración en el tiempo. Aún podrían ser aludidos también quienes se acercan solo a la periferia de la obra literaria sin hacerla vivir dentro de sí.

La Cabaña se ofrece así como el espacio imaginario de la verdadera vida frente a la insatisfactoria realidad: "el espacio de esa hermosa vida que era vencedora del tiempo" (20). La literatura como vida.

\section{Peregrino-Homero}

El peregrino es un personaje construido a través de su conciencia, sin apenas rasgos físicos, y los elementos de su vida externa son los mismos que los atribuidos a Homero desde los tiempos más antiguos. ${ }^{16} \mathrm{El}$ autor lo sitúa así en el siglo octavo antes de Cristo, dato cierto por la documentación de los poemas, y en la isla de Quíos, lugar posible que prevalece sobre otros mencionados como cuna del poeta; su muerte en la isla de Î́os es mucho más incierta. De la leyenda sobre Homero procede la madre del peregrino, "la prudente Creteide", cuyo origen justifica el nombre que quiso dar a su hijo (también atribuido a Homero): "Mi madre [...] nació en Esmirna, junto al río Meleta, y de ahí que, cuando nací, quisieran llamarme Melesígenes” (100). En cambio, su "buen padre” Alcínoo, procede de la Odisea, aunque transformado de rey de Feacia en pescador.

Sin nombre y sin descripción física, sabemos del peregrino por las señales de su edad siguiendo el paso del tiempo. Al principio es "el joven peregrino de impaciente mirada" (59). ${ }^{17}$ Envejece durante los largos años de esclavitud: "sus pies cansados se hundían irremediablemente en la arena de los años” (107). Durante el proceso va cambiando su mirada: "perdiendo la medida del tiempo que marca la curiosidad de la mirada" (107); pero aún se mantiene viva: "fue manchándose de años la piel del peregrino, aunque sus ojos seguían latiendo con la inquieta curiosidad" (109).

Y la vejez llega con señales físicas más precisas: "sobre la poblada barba del joven peregrino había nevado abundantemente el tiempo [...]. El joven peregrino había encorvado y perdido su juventud sobre el remo" $(108)^{18}$. Recluido al final en Íos y convertido en anciano, se apoya en "un rústico cayado", sintiendo "su mirada vencida al mundo de las sombras"; y recuerda a su lejano maestro Aristocles, con el que ahora se identifica: "también él era un anciano aedo, de voz agrietada” (207).

\footnotetext{
${ }^{16}$ Los datos sobre Homero recogidos en la novela son los que a partir del siglo V a.C. se atribuyeron falsamente a Herodoto (pseudo Herodoto).

${ }^{17}$ La mirada será tema de honda reflexión a lo largo de la novela.

${ }^{18}$ Atendamos ya a ciertos recursos de gran lirismo, como esa manera de hacer personal el verbo "nevar".
} 
Precisamente su voz es la otra señal física que le atribuye su autor. Primero en la isla de Zacinto, junto a Eurícide, quien descubre a Odiseo y lo ama a través de la voz del peregrino: "quizás no fuera Odiseo, sino tu voz declinándolo, quien me hiciera verlo más allá de tu palabra. Tu voz corporeizándose en mi mente” (148). Y ya hacia el final, durante el encuentro soñado del peregrino con Nausícaa, en que revive "su juventud de Quíos", vuelve a ser la voz la seña que lo identifica, e igualmente suscita el amor: "apreció, recogiéndola en sus oídos, la voz serenamente viril del aedo, y supo, con la intuición del amor, que aquel hombre dominaba el arte de vivir los días” (184).

Junto a la voz ("viril”, “agrietada"), esos mínimos componentes de la figura del peregrino que indican el paso del tiempo se reflejan en la evolución de su nombre, aspecto tratado con sumo cuidado en la novela. Sin nombre individual, son los adjetivos los que marcan su edad; es al principio "el joven peregrino", hasta que, transcurridos años de esclavitud, pasa a ser "el peregrino", y al mismo tiempo, "el ya no joven peregrino" (109), incluso "el cansado peregrino" (126); muy pronto, en el palacio de Lárico, se convierte en "el peregrino rapsodo" (115) y en el "aedo peregrino" (117). Pero no es hasta el final de la novela, convertido ya en "anciano peregrino" (205), cuando su autor declara sus claves en la respuesta del personaje al ser preguntado su nombre: "Un nombre [...] no es apenas nada cuando el tiempo cae sobre él. Lo importante es la imagen de la vida que dejó en la palabra, lo que él nombró y transformó en la escritura” (203). Y escenificando el desinterés por el nombre, añade: "Creo que Homero [...] Sí, le dije a Euriclea que me llamara Homero" (204). Aún añade el autor un último nombre, el que justifica el título de su novela: en Íos, al final "comenzaron a llamarle «el ciego de Quíos»” (205).

Si leves son las señales físicas del personaje, inmensa es por el contrario la conciencia que lo forma. Los hechos externos narrados no son el centro sino el marco en que se expande el incesante meditar del peregrino. El relato avanza así sobre sus ideas, que siguen un orden libre, asociativo; una idea va trayendo otra, y muchas veces son ideas recurrentes, sobre temas que rebotan sin cesar con cambios de matiz o nuevos enfoques.

Inevitablemente surge aquí el problema del narrador: ¿cómo habla esa conciencia? En gran medida, a través del narrador externo, en tercera persona ("pensó el peregrino...”, "se dijo a sí mismo”), el mismo narrador que cuenta los sucesos ("Y llegó el día”, "Desplegó así la nave su vela”) y que los describe en su forma condensada. Pero ese narrador nos aproxima constantemente al pensamiento del peregrino fundiéndose con él en estilo indirecto libre y con diversas estructuras verbales: "Ciertamente que no iba embarcado en una guerrera nave negra" (59); "Cuando él escribiera" (99); "Sería fácil así [...] todo estaría en la mirada de Euriclea” (106); "lo reflejaría en la escritura de sus hexámetros” (91).

Aún más compleja es la fusión del personaje y su autor, de quien es alter ego, según dijimos. La conciencia de nuestro autor, Antonio Prieto, emprende la búsqueda imaginaria de la conciencia de Homero, quien a su vez busca alcanzar el 
mundo de los héroes de Troya. Un viaje en dos etapas. Ambos coinciden en tres tiempos de la narración: el del autor que lleva las vivencias o las emociones de su presente y todo su conocimiento al tiempo histórico del peregrino (tiempo homérico) y este a su vez llevando su experiencia y los personajes de su vida al tiempo de Troya narrado en sus poemas ${ }^{19}$. Los problemas y las soluciones de la escritura de uno y de otro se confunden en la novela.

Volviendo al Peregrino, prevalece siempre su carácter moral frente a la azarosa existencia y actúa guiado por dos grandes pasiones: la admiración que siente por el mundo legendario de los héroes de Troya y el amor suscitado por la belleza de la joven Euriclea. Ambas pasiones engendrarán su propia meta: la de escribir las historias de los héroes para inmortalizarlos, lo que logrará cumplir, y la meta de alcanzar la plenitud del amor con su amada, lo que solo vivirá, ya viejo, dentro de un sueño con la imaginada Nausícaa.

Elevado al mundo ideal de sus anhelos y proyectos, permanece desligado de cualquier interés material. Desde el comienzo, frente a otros jóvenes, no siente deseo de riquezas: "tampoco pensaba en las rutas comerciales que el mar abría, sino en que el mar lo habían navegado los dioses y aquellos héroes amigos que le acercaba la voz de Aristocles” (52-53). Pero se aleja de esos mismos héroes cuando su afán es mezquino: "la glorificación de la piratería ejercida por los héroes en su búsqueda de botín con el que acrecentar el poder que proporciona la riqueza” (90). Una ambición que es modelo para las naves fenicias (todo un símbolo), y origen del mal social: "practicaban el expolio e incluso se apropiaban en su deshonroso comerciar de frágiles doncellas" (90). Y ambición es la que guía a su anfitrión Pisénor cuando amenaza al aedo peregrino, que tan bien conocía la historia de Troya, para que descubra el tesoro de Príamo, al tiempo que afirma: "es la riqueza el poder que otorga una admiración y un nombre” (177). De Pisénor huirá el peregrino, temeroso de una nueva esclavitud, hacia su soñada isla de Feacia, y antes medita, contemplando el mágico olivo donde habitan las hamadríades: "sabía el aedo peregrino cómo la avaricia desmedida del hombre había talado hermosos árboles segando así la vida de las ninfas acogidas a ellos” (181). Mucho antes, cuando muy joven emprende su viaje, se desprende de las bolsas con queso y miel de su previsora madre: "entendía que era floja presentación del navegante aparecer con aquella protección de madre que lo infantilizaba” (59). Siempre el criterio moral frente a todo sentido práctico para la vida.

\footnotetext{
19 "La novela histórica de fusión mítica creada por Antonio Prieto se forma en torno a un yo que disemina su coherente individualidad entre todas las funciones narrativas, sean textuales (narrador, protagonista, personajes secundarios) o paratextuales [...] En esa diseminación, la actualidad y el idiolecto del autor contaminan sus lecturas sobre el pasado narrado, de modo [...] que el escritor se convierte en un recreador” (G. Garrote (2005), p. 284).
} 
Y también reacción moral frente al sufrimiento de los otros, como en la visión del mercado de esclavos de Lemnos: "esperando ser vendidos o trocados [...] con sus miradas caminando entre la aceptada derrota y la soberbia rebeldía [...]. En sus ojos, avenados por la humedad de la tristeza, brillaba sombríamente la posibilidad de ser comprados para ejercer de remeros en una corva y negra nave" (84). Precisamente, el que va a ser su destino; pero aún su dolor se volverá estupor frente a la crueldad en la visión de los esclavos arrojados al mar: "la nave cargó sus tablas de esclavos, los llevó mar adentro, y allí fue arrojando a la voracidad de las olas a los hombres y a las mujeres de edad ante la mirada atónita de las mujeres jóvenes y los niños esclavos [...] los ojos de los asistentes detenidos, inmóviles, en el oscuro punto de la máxima incredulidad. Ni siquiera la voz o el llanto podían responder a la sorpresa" (107-108).

De igual modo, se enfrenta al sufrimiento propio con serenidad estoica desde el momento en que es reducido a esclavitud: "en el banco de los remeros había dos espacios vacíos que aguardaban la fuerza de los brazos [...] el joven peregrino sonrió tristemente, se acomodó en el banco [...] recordó que también los héroes, en el canto de los aedos, eran mortales que aceptaban el sufrimiento y la muerte como un acto del medido tiempo" (93-94). La misma serenidad manifiesta frente al dolor físico de sus "manos cubiertas de oscura sangre": "Ahora no podría trazar mis signos sobre el papiro" (96). En ese sufrir se escapará su vida, concentrada en escasas páginas de la novela (la gran elipsis): "le tocó navegar amargamente infinitos días [...] perdiendo la medida del tiempo [...] y sumiéndose en un espacio que disolvía lo interno y lo externo de la existencia en una monótona rueda amorfa ajena al destino personal” (107). Pero se salva de la disolución de la conciencia gracias al recuerdo constante de Euriclea y gracias a "cuando escribía o memorizaba hexámetros que recogían la gloria lejana de Troya” (108).

Su sufrimiento físico se acrecienta con el dolor de la conciencia ante su destino: "cuando sus ojos se cerraban lo hacían agarrotados por el cansancio y no dejaban resquicio para volar. Los esclavos no tenían derecho a soñar, no tenían otro derecho que el de conservar instintivamente la vida” (109). Y se acrecienta recordando el lejano tiempo en que soñó con viajar y seguir a los héroes. Aún sufrirá el dolor por su pasado perdido al regresar, ya libre y envejecido, a Quíos: "Y caminó lentamente el peregrino la nostalgia" (126); "Y amargamente se sintió el aedo peregrino como un extranjero" (128).

La experiencia del sufrimiento como esclavo ha venido a sustituir su esperanza de alcanzar conocimiento y gloria, pero todo ello parece responder a una idea planteada antes en el diálogo del peregrino con Paleneo, quien escucha sus anhelos y observa: "acaso te falte sufrir. [...] Sí, el sufrimiento nos va modelando" (89).

A pesar de su doloroso destino, vence moralmente el peregrino gracias a su conciencia de hombre libre: "cuando escribía en su memoria, estos hexámetros, el peregrino no era esclavo” (109). Lo descubre al oírle Lárico, su último amo: "se dijo que aquel aedo [...] tenía la serenidad del hombre auténticamente libre que 
ningún otro hombre podría esclavizar” (119). Lo que comprende Lárico lo sabe ya el peregrino, quien, con pleno conocimiento de sí mismo, condensa así su pasado tiempo después:

embarqué en Quíos para probar la ruta de los héroes. Quería cargarme con sus experiencias y después contenerlas en las palabras [...]. Soñaba en las noches con Troya, con mi Troya recreada [...] navegué largamente como esclavo el ancho océano, descubrí muchas islas e imaginé otras. Pero, especialmente, conocí la soledad y me abracé a la tristeza, me visitó la muerte de los que amaba y vencí el sufrimiento (173).

La contención estoica de la conciencia del peregrino se refleja aún, completando su figura, en su lenguaje. El ancho caudal de sus ideas se depura y condensa en la sobriedad de sus palabras, esenciales: "Padre, quiero navegar" (52), "Sí, padre, necesito navegar" (53). Tal frase, aislada, inserta en la meditación sobre sus anhelos, inaugura su peripecia vital. Y otra frase, igualmente desnuda, cierra, pasados los años, el recuerdo de su juventud en Quíos, cuando soñó con partir en busca de aventura: “Todo eso -se dijo- está perdido” (112).

Del mismo modo justifica su deseo de vivir su destino humano cuando rechaza ante Alcínoo permanecer en el paraíso imaginario de Feacia: "Porque yo -sonrió el aedo peregrino- no soy la imaginación de un otro” (195).

Conciencia y lenguaje condensado se elevan en un verdadero clímax repleto de significados cuando el peregrino aplaza su recuperada libertad como esclavo para cumplir aquel sueño primero de fijar por escrito la memoria de los héroes: "Terminaré mi Ilíada en tu palacio, será tuya, y luego la recitaré para tus oídos en sucesivos días. Después probaré nuevamente lo que llamamos libertad” (120). Su libertad es antes que nada crear su obra, lo que convierte en muy dudoso el significado convencional de la libertad. Todavía hay más, creará su obra para entregarla, renunciando a ella pero existiendo en ella (recordemos, "un nombre no es nada”); es el modo anónimo de alcanzar su sueño de gloria, de perdurar.

El significado moral del peregrino aún nos ofrece otro ángulo, el de su fidelidad inquebrantable frente a toda adversidad: fidelidad a cuantos amó desde el comienzo de su vida, presentes en su memoria con imagen viva a través de los años; fidelidad a su amada Euriclea, evocada hasta el final como aliento de su existencia; y fidelidad a su gran proyecto de fijar por escrito los cantos heroicos, que forjó siendo joven y al que dará término siendo ya anciano.

Acerquémonos a esos personajes cuya existencia completa la imagen del peregrino, y más adelante nos asomaremos a su universo de ideas.

\section{Peregrino-Odiseo, y el coro de personajes}

A lo largo de la novela se van sumando personajes ocasionales, muchas veces sin nombre, meros comparsas, como los jóvenes amigos de Quíos, o como los 
jóvenes nobles de Zacinto y de Corcira que acogen a nuestro aedo, o como los capitanes de algunas naves. Anónimos también, pero con más presencia como interlocutores, son el capitán del barco que conduce al aedo a Zacinto, o como el piloto que lo despide en Íos al final preguntándole su nombre; igualmente lo son, en su regreso a Quíos, la molinera y el adivino, cuyas respectivas respuestas cierran su pasado y abren su futuro.

Ocasionales también, pero señalados con nombre y con mayor significado, van sucediéndose otros personajes, como la hetaira Praxila, amante de Paleneo en Lesbos; o como la hetaira Yanira, muy humanizada, raptada muy joven en Esmirna, que dialoga tristemente con el peregrino sobre su destino y que desea haber sido amada como Euriclea (99). Se añaden el culto y generoso Lárico, que liberará al aedo, o el ambicioso y cruel Pisénor, dispuesto a esclavizarlo para obtener las imaginarias riquezas de Troya. Y ya en la corte soñada de Alcínoo, el sabio Aqueneo, el pretendiente Euríalo, o Areta, madre de Nausícaa (a la que regresaremos junto con Alcínoo). Aún cabe recordar dos sombras fugaces, de valor antagónico en el relato: el temible noble orgulloso de su poder, reducido a su indumentaria (86); y el joven que destaca entre los que escuchan al aedo al final (“de ojos más nutridos en la curiosidad, en que inmediatamente revivió aquella su lejana juventud”, 207), y que representa una emoción.

Los otros personajes, que son los seres amados por el peregrino, encierran mayor complejidad en su significado, en su creación y, algunos, en su procedencia. Todos aparecen muy al principio del relato y todos avanzan tras los pasos del peregrino que los lleva en su pensamiento, como una escena fija que aparece de modo recurrente.

Quedó ya indicado el origen de Creteide como madre del peregrino, copiando el legendario nombre atribuido a la madre de Homero. Pero el personaje es más que un nombre en la novela, más que el epíteto que la acompaña, y que el oficio de partera que se le atribuye. Es la confidente de su hijo en el gran proyecto de escribir; sus sagaces preguntas generan la lúcida exposición de lo ideado por el joven: " $-\dot{¿} Y$ esa escritura habla? -Sí, claro que habla. Y espero que siga hablando cuando tú y yo hayamos desaparecido de Quíos” (32). De igual modo, manifiesta temor frente a su sueño de viajar (“Tú, hijo, aún eres muy joven”, 40); y lo repite en su diálogo con el padre, inquieta por sus proyectos y anhelos. Y cuando el hijo parte a su aventura, le entrega, previsora, la bolsa con queso y miel. Apenas más es Creteide en la novela, pero permanecerá en ella resguardada en la memoria del peregrino, muchas veces recordada.

Alcínoo es en realidad dos personajes ${ }^{20}$, ambos, de ficción. Inventado por nuestro autor de la novela, es "el buen padre" del peregrino, que completa la

${ }^{20}$ En la meditación del peregrino se funden los dos personajes, sugiriendo que en sueños había trasladado el nombre de su padre al padre de Nausícaa (201). 
educación del hijo con la experiencia acumulada en sus viajes como pescador, en los que conoció muchos lugares y oyó historias antiguas. Su nombre es tomado del personaje de la Odisea, el rey de Feacia, que también reaparece como tal en la propia novela cuando el peregrino, transformado en Odiseo, llega a la isla en sueño y es llevado a su presencia para ser honrado como huésped; esta vez es el Alcínoo de la epopeya homérica. No obstante, recordemos, el proceso es invertido por nuestro novelista, según lo cual, los seres de la vida del peregrino-Homero fueron llevados a la Odisea, lo que produce un movimiento triangular.

Junto a los padres es maestro del protagonista el anciano aedo Aristocles ("de agrietada voz"), quien con sus relatos sobre los héroes troyanos encendió en el joven todos sus anhelos, el deseo de vivir hazañas y el proyecto de escribirlas. Representa el oficio de aedo, ya cargado de años y experiencia, y anticipa la imagen del peregrino, que se identificará con él al final. Pero su nombre no es invención, sino homenaje del autor de la novela al filósofo Platón, pues, como sabemos, este último sería su seudónimo, según la tradición, y su verdadero nombre habría sido Aristocles. Volveremos sobre el filósofo para ver otras implicaciones en la novela.

Con Eumeo se cierra el cuadro de los maestros del joven, o más bien, de los modelos. Como Alcínoo, Eumeo procede de la Odisea, pero se afirma que es el peregrino-Homero quien lo lleva desde su vida a su escritura. Esta vez el movimiento del personaje será circular: había sido esclavo en Ítaca esperando alcanzar la libertad al regreso de su amo y ofrecía al protagonista la experiencia del pasado, no las referencias, como Aristocles, a quien Eumeo corregía. Será evocado muchas veces a lo largo de la novela y regresará a la Odisea como personaje creado por el peregrino: “Algún día me gustaría escribir de Eumeo, trasladarlo al tiempo de los héroes y que viviera con alguno de ellos, con Odiseo, por ejemplo, porque sería resaltar el valor de lo humilde y de la fidelidad” (83). En realidad, el novelista Antonio Prieto está imaginando en esas palabras el propósito que hubo de tener Homero al crear el personaje para elevar su valor humano junto a las hazañas heroicas. Pero el Eumeo de la novela tiene otros significados: anticipa el dolor que sufrirá el protagonista como esclavo ("también de niño fue esclavizado por los fenicios”, 85). Y sobre todo, prevalece en el relato de la muerte de su madre y de su "entierro humilde", exento de rituales. De sus palabras recordará siempre el peregrino la imagen de Eumeo cerrando los ojos a su madre: "sus dedos aún conservaban el suave tacto de los párpados maternos cuando fueron cerrados para andar brevemente la oscuridad de esta vida” (85). ${ }^{21}$ Y recordará también una novedosa idea religiosa: "Eumeo aseguraba algo mucho más hermoso como era la existencia de una luz nueva y distinta por la que podía caminar la mirada de su

${ }^{21}$ La importancia concedida a la muerte de la madre de Eumeo parece contener elementos autobiográficos del novelista, remarcados tal vez en la imagen "abrazado de su esposa y sus hijas” (83). 
madre” (83). Esa luz consoladora revelada por Eumeo parece adelantar un significado trascendente de la vida humana, como anacronismo de la concepción religiosa cristiana que ha de llegar en siglos futuros. Y todavía Eumeo añade a sus significados el aparecer convertido en padre de la siempre amada Euriclea, a la que hemos de dirigir nuestra lente.

Cerrando el coro de los personajes que acompañan al peregrino, destaca con especial valor Paleneo, ${ }^{22}$ el amigo y maestro que le acompaña en su aventura vital compartiendo con él los años de cautiverio. Desde el comienzo del viaje, viene a sustituir a la madre del joven en su función protectora: su primera palabra es un ofrecimiento, precisamente de queso, como el que el joven recibió de Creteide y había abandonado antes de partir. Desde ese punto, Paleneo será siempre el hombre instalado en la realidad práctica, y guía del peregrino, mientras este permanecerá refugiado en sus meditaciones. No comprenderá las elevadas reflexiones del joven amigo, pero será su maestro para la vida, para sus goces y para sus sufrimientos (recordemos: "acaso te falte sufrir", 89): le invitará a buscar placer con una hetaira; o le anunciará el doloroso destino que les espera: "Ya somos esclavos" (94); y verá la pérdida de todo futuro para ellos: "ahora no somos ya ni tiempo" (104).

También curará Paleneo las manos del joven, ensangrentadas de remar. Juntos envejecerán en la desgracia, y la muerte alcanzará a Paleneo en el palacio de Lárico antes de recobrar la libertad. En ese punto, el afecto fraterno del peregrino se eleva a amor filial, y, al cerrar los ojos del amigo, recuerda a Eumeo y aquella esperanza de "una nueva y eterna luz en la que jamás la mirada se agotaba” (115).

El intercambio de personajes entre las epopeyas homéricas y la novela, alguna vez confundiendo incluso sus tiempos (Eumeo, por ejemplo), se produce sobre todo con respecto a la Odisea, en la que encuentra el novelista modelos humanos, no heroicos, en los que reconocerse ${ }^{23}$. Esta elección expresamente defendida por el peregrino, se extiende en ocasiones a los héroes de la Ilíada: "se sentía más cercano a la humanidad de Héctor que a la superioridad de Aquiles" (42). Sobre todo, como creación suya depositada en el poema, se fija en el episodio que enfrenta a Príamo con Aquiles por el cadáver de Héctor, ambos revestidos de humanidad: el dolor del padre y la piedad por el enemigo: "el anciano Príamo y el fiero Aquiles lloran conjuntamente, pueden mirarse frente a frente por vez primera y sentir cómo por la luz tendida por la mutua mirada crecen unas sensaciones que destierran la ira y el odio, y un hombre comprende a otro hombre” (130).

\footnotetext{
${ }^{22}$ El nombre del personaje podría ser un homenaje a la figura histórica de Aminias Paleneo, el capitán ateniense que arremetió el primero contra una nave persa dando inicio a la batalla de Salamina (480 a.c.).

23 "lo que importa no es un tiempo al que no podemos identificar, ni un espacio en el que no quedan ni siquiera ruinas. Es la capacidad de crear seres vivos” (M. Alvar, 1996 b).
} 
Pero busca un héroe en el que reflejar las experiencias vividas: "no a uno de los inflexibles héroes que se batieron en Ilio sino a uno que [...] cultivara el arte de la inteligencia y la palabra [...] capaz de sentir piedad” (124). Así elige a Odiseo, cuyas peripecias narrará como aedo y con el que muy pronto comenzará a confundirse: el mar que navegó tantos años "era el mismo mar que había peregrinado Odiseo llorando la ausencia de Ítaca" (135); y se representa confusamente como su compañero y como su creador: "navegué con Odiseo, al que saqué de Troya y le di mis experiencias" (139).

El narrador de la novela, a través de la meditación del peregrino, va repasando los famosos episodios de la Odisea, pero el propio peregrino protagonizará el episodio de las sirenas, al fin convertido en Odiseo. Continuará así, entrando y saliendo del personaje, hasta su llegada a Feacia, donde es recreado el episodio homérico mediante la fusión del peregrino y Odiseo ${ }^{24}$; de modo que el encuentro de este con Nausícaa es al mismo tiempo el reencuentro del aedo con su Euriclea. Más allá, descubrimos así una estrecha fusión entre el autor-narrador, el peregrinoHomero y el personaje de Odiseo, todos ellos fundidos en la atracción por una figura femenina vestida con diversos nombres.

\section{Todas y una: Euriclea, Nausícaa, Ifigenia, Eurícide, Helena, Yanira}

En la Nausícaa homérica se modela la figura de la amada. En la playa de Quíos, contemplándola desde una colina, ve por primera vez el peregrino a Euriclea ${ }^{25}$, y la imagen de esa visión será la más poderosa, la que se repetirá sin cesar en su memoria, como uno de los principales elementos recurrentes de la novela. Y no solo será recordada la imagen de la joven sino una secuencia, la escena entera de esa visión: "el movimiento de Euriclea, jugando a la pelota con sus amigas sobre la cálida arena. Miraba el joven peregrino las perfectas piernas de Euriclea trazando armónicamente en el aire un dibujo fugaz" (42).

La luz de su mirada será la fuente de todo bien: sus ojos son generadores de vida ("en ellos siempre predicaba la llama de la vida”, 38), de belleza ("su belleza deseaba transformarse en unos signos que la expresaran”, 38); y vendrán a ser inspiración para el peregrino (“convertir la realidad en lenguaje, especialmente aquella realidad que bebía en los ojos de Euriclea”, 42). Revistiendo al personaje de

\footnotetext{
${ }^{24}$ Aquí la fusión mítica se produce con el personaje. "Estos mitos o historias ejemplares son los vehiculados por la tradición literaria y que le sirven a Prieto como crisol donde llevar a cabo su operación de fusión, mitos que a su vez fueron utilizados por los escritores a los cuales él se une íntimamente por simpatía de sentimientos y de estados de desdicha o añoranza. Le suministran el patrón previo y le proporcionan la distancia imprescindible para transformar el dolor en palabra” (M. López (1992), p. 346).

${ }^{25}$ Es en la obra de Homero el nombre de la nodriza de Odiseo, quien lo reconoce pasados los años cuando regresa a Ítaca.
} 
dimensión homérica, su nombre será adornado con un epíteto que expresa esa luz: "la de los ojos encendidos".

De modo que Euriclea es sobre todo luz de su mirada y movimiento de sus piernas, con unas notas sensoriales añadidas, como sus pechos que "apenas desbordaban el cuenco de las manos” (36); y con mayor intensidad, la muchas veces recordada sensación de su proximidad física, pura sensualidad: "Euriclea se acercó tanto que pudo oler en su piel el perfume salvaje del mar y aun rozar sus bellas mejillas, que tenían el ligero temblor de la brisa” (60). Aún es algo más, toda ella aparece al principio como un relámpago de luz: "tuvo la impresión de que la transparencia de luces que alimentaba la colina modelaba su figura creando una sinfonía plástica más propia del movimiento de una diosa que de una realidad humana” (36).

Su imagen suscita el amor y lo simboliza para el peregrino, quien proyecta la obra que ha de escribir en torno a ese sentir, el que no habían seguido Aristocles y los otros aedos, más interesados en las hazañas de los héroes ("habían perdido la línea de que primero era el amor y después la guerra”, 41) y olvidados del universo femenino y del vínculo amoroso simbolizado por la figura de Helena: "los pies ligeros de Aquiles, calzados en su cólera, merecían mucha más atención que la hermosa mirada de Helena” (39).

Euriclea se eleva así a la categoría de un ser ideal, y desde ese punto le es posible adoptar diferentes apariencias. En la novela, toda joven figura femenina que se aproxime al peregrino y suscite su amor sufrirá una identificación con su amada de diversas maneras: "[Euriclea] podría ser en su mirada la mirada de otras mujeres [...] la esencia de la vida con el disfraz de otros nombres" (36). De tal modo, su imagen se fundirá incluso con el personaje mítico de Helena, la desdibujada figura de la epopeya: "para imaginar la lejana y solo oída mirada de Helena tendría que desplazar a ella la mirada de la joven Euriclea” (39). Una identificación que es recurrente en la novela y lleva a la joven amada a un tiempo muy lejano ("Debía de ser externamente como lo era actualmente Euriclea", 104). En realidad, es situada en cualquier tiempo, conservando una juventud atemporal, mientras transcurre la vida del peregrino, que incluso desea identificarla con Atenea, a quien busca como "protectora de la inteligencia y de las artes" (49).

A poco de iniciar su aventura, durante su diálogo con Yanira, la joven raptada mientras jugaba en una playa y convertida en hetaira, ve en ella a una Euriclea que no llegó a ser; y la propia joven anhela serlo, haber sido esa mujer amada: "que alguien pudiera decir de mí como tú has dicho" (101).

Una mayor identificación se produce con la joven Eurícide, que escucha al peregrino cantar aventuras de Odiseo en el palacio de Zacinto: "se confundían en él los nombres de Eurícide y Euriclea en un común sonido, y aún más: le parecía que Eurícide era la imagen de la juventud de Euriclea corriendo por la playa de Quíos” (148). Pero la joven no es solo la imagen, se convierte también en inspiración para el peregrino anunciándole su visión del encuentro de Odiseo con Nausícaa: "He 
visto a Odiseo llegar agotado por el mar a una isla y despertar luego del sueño ante las voces de unas muchachas" (147). De nuevo se funden libremente los argumentos de la Odisea y de la novela, otra vez subvirtiendo todo orden, pues el conocido episodio de Nausícaa no es inspirado siquiera por el peregrino sino por la figura fugaz de Eurícide, quien a su vez afirma haberse inspirado en su voz al escucharle.

Yanira y Eurícide funcionan como transición en el recorrido que parte de Euriclea y conduce a Nausícaa ${ }^{26}$, para alcanzar con ella la plena fusión. Así se confirma que en realidad el personaje homérico ha inspirado la figurada Euriclea.

El peregrino, por su parte, recita y escribe sobre Odiseo, pero también se identifica con él, y se confunde con él, según vimos: “yo me acompaño de Odiseo y con Odiseo me libero de mis largos años de esclavitud” (150).

Todo el proceso de identificaciones prepara el reencuentro del protagonista con su amada bajo la imagen de Odiseo y Nausícaa en una recreación del episodio homérico. Es el momento culminante de la novela, pero antes se había anunciado con notas dispersas, como una pasajera visión en los años de esclavitud: "el dibujo de una hermosa isla en cuya playa jugaba a la pelota una preciosa muchacha que era Euriclea” (107). O como una imagen ubicua de la amada: "aún juega por las islas remotas" (168-169).

El encuentro se produce, claro está, en Feacia ("una isla apartada en medio del mar y que aman los dioses”, 184) ${ }^{27}$, a cuya playa es arrojado el peregrino tras un naufragio, y donde protagoniza sin nombre todo el episodio homérico, pero recreándolo para poder cumplir sus anhelos, aunque todo suceda en un sueño. "Creo que Euriclea eres tú”, dice el peregrino a Nausícaa, y entre ellos nace y se realiza el amor con imágenes sensuales ("se acercaron sus bocas para compartir el aire", 190), envueltos en un marco de belleza: "Crecía cerca un tupido cañaveral que disputaba las humedades del río a los alegres acebuches de fruto pequeño, dejando en medio ocultos y algaidos espacios que sombreaban las ramas. Allí se adentraron la

\footnotetext{
${ }^{26}$ El valor de su figura para Prieto se reproduce en muchos de sus escritos. Muchos años antes de escribir la novela alude así al personaje: "el mundo debe a Nausícaa el mejor latido lírico que yace en la Odisea” (A. Prieto (1972), 161). Años después, en otro famoso texto, el autor ha convertido ya a Nausícaa en un mito definitivo, que concentra en sí el ideal absoluto: "Te escribo, Nausícaa, desde una distancia que los hombres llaman eterna pero que no ha podido ni podrá apagar el movimiento de tus labios y el verde de tus ojos sembrando mi palabra” (A. Prieto (1985), p. 73).

${ }^{27}$ La isla será tema en la siguiente novela de Prieto (1997): "Isla Blanca; título que hace referencia a la isla de Feacia, amada por todos los dioses y en consecuencia inexistente [...] un espacio arcádico e ideal” (J.M. González (1999), p. 198).
} 
hermosa Nausícaa y el joven peregrino” (193). Esos alegres acebuches se reiterarán hasta el final del relato para aludir al encuentro de los amantes ${ }^{28}$.

En medio del diálogo con Nausícaa se produce el laberinto argumental, una vez más, y regresamos a la novela. La libertad narrativa es total. Toda la vivencia del encuentro con Nausícaa es relatada mucho antes, como una visión premonitoria, cuando el peregrino explica quién es Euriclea, añadiendo a la escena la vieja imagen de Quíos:

es una muchacha que, animada por la ojizarca Atenea, después de lavar las ropas en las hoyas del río y bañarse en el mar, ungida de aceite brillante, está jugando a la pelota con sus siervas en la playa de Quíos. Su hermosa piel no la roza el tiempo, al igual que no roza la piel de las hermosas diosas, y una vez, especialmente una vez, sentí el nacimiento de la invitadora sonrisa en sus labios y el temblor de la iluminada ilusión en sus ojos. Yo consumí infinitos días navegando estérilmente los mares, cubriéndome con el salumbre, hasta tentar ya la oscuridad, pero Euriclea quedó anclada con su juventud en sus ojos y la mirada la repite en Quíos trenzando el amor con sus piernas cuando corre a rescatar la pelota caída en una gorga del río donde mis ojos la descubren” (140).

Este sucederse y fundirse la imagen de la amada ideal con sucesivos personajes viene a perpetuarla y a eternizar al mismo tiempo el sentimiento que ha inspirado. No son muchas mujeres sino una, formada con rasgos estáticos que se recrean sin cesar, como variaciones de una melodía. ${ }^{29}$

Pero aún queda una última recreación, o tal vez la primera, y para reconocerla debemos regresar a La Cabaña, cuyo relato enmarca la novela. Allí el autornarrador anticipa la muerte del peregrino, como ya vimos, y su amada Ifigenia, su musa, es el germen de todas las amadas del peregrino: "La mirada de Ifigenia tomando a veces el color de los ojos de Euriclea y otras el de Nausícaa, estuvo navegando para que se hicieran palabra aquellos numerosos días nacidos hace siglos en la abrupta Quíos y cerrados en una pequeña isla adueñada del silencio” (211). ${ }^{30}$

Ifigenia es la creadora de la vida pasada y presente, la que rescata al peregrino y sus poemas heroicos, y a la que busca el autor-narrador para poder escribir su novela: "navegar los amplios mares e ir corriendo al encuentro de Ifigenia, la de los ojos encendidos, y en ella renovar cómo su voz cubría mi escritura” (216). El

${ }^{28}$ Suárez de la Torre juzga el episodio: "magnífica la fusión entre realidad e imaginación [...] forma de decirnos que la fuerza de la creación literaria nos puede conducir al logro de los mayores anhelos” (E. Suárez (2008), p. 567).

${ }^{29}$ Este multiplicarse la amada ideal es el modelo contrario de la Poliginia inventada por Rubén Darío (“una y todas”), que reúne en sí misma a las otras mujeres.

30 "Igual que Petrarca creó a su Laura, Prieto, no menos renacentista, no menos humanista, no menos poeta, desea crear una mujer ideal, un sueño hecho mujer [...] para que la vida tenga un motivo digno de permanencia en el mundo” (I. Colón, 2008). 
mismo epíteto para Ifigenia que para Euriclea o Nausícaa; y si ellas son la misma, también son lo mismo Homero, el peregrino y el autor-narrador, y más aún, si Ifigenia es su inspiración, todos ellos son al final el autor de la novela: "La mente era quien creaba la realidad” (206).

\section{El incesante meditar del peregrino}

Representarse en su escritura es lo que busca Antonio Prieto y ansía su personaje el peregrino, al que recordamos en constante meditación por la que fluye una constelación de ideas. Muchas de ellas han ido brotando hasta ahora, pero aún atraen la atención algunas otras que es preciso intentar abarcar.

Del mundo real al ideal nos guía la conciencia que nos habla, y en el punto de partida de ese transcurso encontramos el juicio sobre la sociedad de los hombres: "encontré demasiadas ambiciones, demasiada avaricia y guerras que alimentaban la muerte” (194). Un juicio nacido de la experiencia, no de la especulación, como víctima y como testigo del sufrimiento de otras víctimas, como Eumeo, Paleneo, Yanira, los esclavos, a los cuales desea destacar frente a la arrogancia de los poderosos: "resaltar el valor de lo humilde y de la fidelidad" (83).

Pero el hombre podía ser algo más: "había aprendido cómo los mortales podían sufrir, desesperarse, albergar la cólera, padecer las miserias y necesitar el amor" (112). Ese anhelo de amor es ya elevación sobre la limitada realidad material. Más aún, cuando se somete el sentimiento a una actitud moral, como cuando rechaza el peregrino el ofrecimiento de Yanira de sustituir a la amada Euriclea: "no es bueno vivir a una persona con otra. Creo que se lastima a ambas y se lastima el que lo hace” (101). Amor, fidelidad, y mucho más, siguiendo en el proceso de idealización: "la única realidad, donde las estrellas fluyen del fondo de los mares, era la realidad que formaba el amor" (206). Alcanzada tal noción, se rompen los límites y se avanza hacia un significado trascendente en el afán de perdurar: "Únicamente el amor ganando la mirada podría combatir contra la máscara del tiempo y acercarse así a la eternidad de los dioses” (149).

En este proceso de abstracción que lo acerca a lo divino, el amor se conecta con otro ideal, la noción de belleza: "La única realidad era el amor extendido desde sí mismo y persiguiendo a la inquieta belleza” (54). Así, el amor que diviniza al hombre busca a la belleza que es expresión de la divinidad: "el mundo de la incontenible belleza en el que un dios se reencuentra en un hombre" (147). Y su noción también estimula el anhelo de trascendencia: "se revelaba la belleza como una acumulación eterna de la muerte" (44). Pero regresando al plano vital se interponen los límites del hombre: "aquella belleza que sería un gozo eterno si pudiera conseguirse la unión plena y no solamente una felicidad medida por el acoso del tiempo" (95). Naturalmente, toda la concepción nos remite al ideario platónico, del que es expresión. 
En torno a los límites de la existencia se genera otro núcleo de ideas ${ }^{31}$ y se configura una visión del ser hombre, desde el punto de partida: "Todo lo anterior, desde la primigenia gestación del Cielo, las Montañas y el Ponto, engendrados por la Tierra o Gea, era prehistoria, porque la vida estaba en aquel hombre que caminaba erguido aceptando el destino de su nombre de poder mirar hacia arriba y contenerse en la palabra” (165). El hombre es el que piensa y se expresa, lo que significa conciencia de sí mismo, incluso percepción de todo cuanto existe: "no podía existir nada para nosotros si no lo convertíamos en imágenes, en ideas” (77). El hombre da existencia a la realidad exterior. Por su conciencia se descubre a sí mismo en soledad radical: "tú puedes ser la compañía de ti mismo" (130). Siente anhelo de libertad, pero descubre que esta ha de nacer de sí mismo: "sabía que la libertad era especialmente un gozo interior que nos habita" (165). Su conciencia es al mismo tiempo fuente de dolor frente a la felicidad de la inconsciencia: "las aves y los pájaros cantando el gozo de sentirse vivos y desconocer que eran mortales" (186). Pero cabe al hombre vivir en su mundo de plenitud imaginario, creado por su conciencia: "quizás la vida también pudiera asomarse en el espejo de un mar que reprodujera su dibujo invertido y trazado por la imaginación” (197). Lo que no desconoce el hombre es el destino de su vivir: "caminamos por la senda del tiempo hacia la eterna noche oscura. Somos el tiempo" $(104)^{32}$.

Nace así su deseo de permanecer, de ser recordado: "que alguien oyese su voz, sentirse aún vivo en su voz" (100). Y ese afán de permanecer es satisfecho en la novela, por una parte, por la obra creada en la escritura: "si su escritura vencía el

31 "En casi todas las creaciones de este humanista late un fondo muy claro de lateralidad, de melancolía, de destierro, no en un sentido físico [...] sino metafísico” (Á. García Galiano (2013), p. 90). “Donde otros buscan (o inventan) ríos metafísicos, Prieto los nada” (Ibid., p. 55). Esta misma idea la atribuye Cortázar a la Maga en Rayuela.

32 Profunda conocedora de la obra de Antonio Prieto, Pilar Palomo vio con sorprendente anticipación la preocupación que orientaba la evolución de su narrativa: “Así, de manera cada vez más acusada, la novelística de Prieto se ha centrado en una problemática trascendente, dolorosa y conscientemente traspasada por una suprema realidad: la muerte. La muerte y el hombre, y sus mutuas relaciones, gravitando sobre conceptos universales vida, civilización, fe, naturaleza- cuya explanación novelística coloca a la obra de Prieto en caminos poco transitados por la realista novela española. Podría, incluso, aplicarse a su obra el calificativo de cerebral, si, al igual que es trascendida la realidad externa que la soporta, ese cerebralismo no fuese también trascendido por un humanismo vivificante, a veces acuciante” (P. Palomo (1967), p. 727)

Haciéndose eco de estas palabras, M. Hernández Esteban afirma tiempo después (2002, p. 85). "El conflicto existencial, que es el gran conflicto de la narrativa del escritor y de la literatura de todos los tiempos, el eje vertebral vida/ muerte, el conflicto caducidad/eternidad, etc. [...] Y es la acuciante necesidad de expresar esos esenciales contenidos bajo una forma encubierta, literariamente apropiada, lo que le lleva al mito". 
tiempo" (130). Aunque no sirve de consuelo para el deseo de permanecer en el vivir como hombre, el mismo deseo que lleva a Odiseo a renunciar a la inmortalidad ofrecida por Calipso: "Porque amaba la vida [...] porque amaba medirse con la mortalidad de la vida" (189). Deseo con el que de nuevo se funde el peregrino: "Odiseo le prestaría su vida [...] el valor de rechazar por la vida la tentación de ser de muerte y vejez eximido" (205). Al final, de forma reiterada, se ofrece la esperanza y la convicción de la trascendencia de la vida humana en esa luz anunciada por Eumeo: "algo interior le aseguraba que más allá de esta luz que compartíamos en la vida, de la mirada en la que vivimos, existía otra luz infinitamente más limpia en la que los ojos de su madre seguirían mirándole” (82).

Con la alusión a esa luz se alcanza el pensamiento religioso. En realidad, hay un nivel previo por el que la cosmogonía griega fundamenta todo el relato de la vida del peregrino, quien evoca sin cesar episodios mitológicos. Se reconstruye con ello el universo homérico en el que los dioses aparecen sujetos a las mismas pasiones que los hombres y mezclados con ellos: "Quizás [los dioses] hubieran sido hechos por los hombres a su imagen, dándoles igualmente sus costumbres” (61). Pero su extensa presencia en la novela solo pretende constituir un rico depósito cultural, cuyo principal valor es literario.

En efecto, es con la alusión a la "luz nueva”, breve y ocasional en el relato, con la que nos situamos en el nivel de lo religioso, y no solo, porque creando un puente con lo mitológico, al tiempo alcanzamos la concepción monoteísta: “colocados por Zeus en su olímpica creación” (165). Así, Zeus, entre cuyos atributos no estaba el de "creador", pasa a representar a Dios.

Una visión plenamente religiosa se produce mientras el peregrino contempla de noche los astros en un estado de beatitud. Se inicia con la imagen mitológica de Atlas sosteniendo la bóveda celeste, y sobre ella se deriva una visión trascendente: “descubrió [...] la existencia de una armonía que mantenía [...] la espléndida bóveda celeste en la que brillaban extraordinariamente aquellos puntos lejanos y luminosos en cuyo centro esférico existía un ojo que miraba a los mortales y les enviaba su luz" (71).

He aquí el origen de esa aludida "luz nueva" que procede de un ojo que nos mira desde el centro del cosmos, con el que nos transmite el autor peregrino la idea de Dios: "Es la armonía [...] Es la gran armonía quien realmente las sostiene [...] Las estrellas, las esferas [...] Es la armonía celestial” (72).

Antonio Prieto lleva así a la meditación de su personaje la teoría pitagórica de la armonía de las esferas, cuyo funcionamiento ordenado se basaría en los números, y cuyo movimiento generaría un sonido, igualmente ordenado, que sería la música:

esas esferas se mueven y miran como nosotros, y de alguna manera su movimiento tiene que producir un sonido [...]. Todo lo que se mueve produce un sonido, aunque a veces sea imperceptible [...]. Es posible que los ciegos, acumulando el sentido que les falta al oído, puedan escuchar el sonido de las 
esferas [...] había un aedo ciego que afirmaba que la música brotada de su instrumento era el eco de la música que producían las esferas al moverse” (73).

Se interpreta así la visión de la música como expresión de la armonía que preside el universo, pero encontramos otra referencia que nos conduce del mundo filosófico de la Antigüedad al mundo literario del Renacimiento español, en busca de la clave que oculta al aedo ciego; y nos parece que representa a Francisco Salinas, ${ }^{33}$ el músico humanista que desarrolló la teoría pitagórica con un sentido cristiano, según la cual la música sería expresión física de la armonía celestial que es reflejo de Dios (“un ojo que miraba”). ${ }^{34}$ Y más allá, este homenaje a Salinas, introducido por el autor de la novela, se puede convertir en homenaje indirecto a Fray Luis de León, quien escribió la célebre Oda a Salinas y quien parece ser aludido con esa palabra tan destacada por el autor, "plectro": "cuyo sonido depende de la formación de la cuerda y del sonido que le des con el plectro o la mano" (73); es decir, el "plectro sabiamente meneado" 35 .

Muy ágilmente el autor ha creado un hilo conductor del pensamiento clásico que procede de los pitagóricos y de Platón, y que pasando por el Humanismo del siglo XVI, conduce hasta él mismo en su novela.

De todas las esferas, una "estrella apartada" mira siempre en la noche al peregrino como su interlocutora mientras medita. En su luz identifica su mundo ideal, que es a veces Euriclea, la belleza, el amor, y que rige toda su realidad. Nos hallamos, según venimos viendo, ante una interpretación neoplatónica que ha culminado en la visión de la armonía universal, y con la que aún se nos ofrece una propuesta: "dejar el mundo externo como un misterio de los dioses y no intentar averiguar, sino contemplar, la nocturna armonía de las estrellas, en las que acaso residiera nuestra vida” (137).

Frente a la ciencia, "no averiguar", sino "contemplar", y en ello se resume la incesante búsqueda del protagonista en pos de su ideal, del mundo ideal que le ha llevado a la percepción de la armonía de Dios. Es una propuesta que se identifica con la aspiración del platonismo cristiano; en palabras de Fray Luis: "Traspasa el aire todo / hasta llegar a la más alta esfera / y oye allí otro modo / de no perecedera / música, que es la fuente y la primera”. ${ }^{36}$

\section{La mirada, la palabra, la escritura}

\footnotetext{
${ }^{33}$ Francisco Salinas (1513-1590) fue profesor en Salamanca y en 1577 publicó De Musica libri septem, donde vertió sus teorías filosófico-musicales, en el mismo año su amigo Fray Luis de León le dedicó su oda.

${ }^{34}$ Ese "ojo" sería el Uno o el Centro del Neoplatonismo cristiano.

${ }^{35}$ Oda a la vida retirada.

${ }^{36}$ Fray Luis de León, Oda III, a Francisco de Salinas.
} 
La conciencia del peregrino se asoma al mundo a través de los sentidos, y por uno de ellos alcanza la más alta percepción: "La vista [...] el más noble de los sentidos y no el tacto o el gusto, que carecen de la medida de la luz" (95). La luz y la mirada que discurre en ella se erigen, más que en el símbolo, en la representación de la vida: "La mirada era la expresión de la vida, incluso su creación” (34). Y más todavía: "La mirada era la propia vida" (95). Como su correlato a lo largo de la novela, la oscuridad es el destino fatal y hacia ella se mueven todos los personajes, excepto Euriclea: "Allí latía Euriclea, con sus ojos oscuros movidos por el gozo, perennemente joven” (206).

Por la mirada se conecta todo cuanto existe generando la incesante marcha de la vida: "la facultad del ojo humano para transmitir a los sentidos ciertas impresiones que nacían de la mirada de otros ojos que le enviaban su luz renovadora” (33). Desde el principio, la mirada del peregrino busca el conocimiento, y ese aprendizaje de la vida solo puede hallarse en la mirada de los otros: "necesitaba vivir, navegar [...] aprendiendo con ello la mirada de las gentes” (40).

Como es natural, en la conexión de las miradas nace la conciencia del amor, aún sin nombre: "el presente que iba naciendo en las sensaciones transportadas en la luz que engendraban las miradas entre Euriclea y el joven peregrino” (56).

En la mirada se pueden fundir un pasado y un presente que se enlazan como imagen de la felicidad: "Se unieron en la mirada [del aedo peregrino] su lejano tiempo de Quíos y la actualidad de aquel momento proclamado por la libertad" (119).

O también, dos miradas separadas en el espacio pueden encontrarse a través del cielo, o mundo ideal, contemplado por ambas: "[Euriclea] quizás hubiera esperado que el cielo, como un espejo, reflejara la luz de la mirada en dirección a Lesbos para encontrarse en algún punto del espacio con la luz de la mirada del joven peregrino dirigida a Quíos” (71).

Pero la intensidad de las miradas tiende a desvanecerse si son sometidas a la lejanía del espacio o del tiempo: "tendría que buscar los ojos de Euriclea por imaginados espacios porque el tiempo había teñido con la distancia aquella su mirada en cuya luz se transportaban las hermosas sensaciones” (126).

Esa disolución la sufre especialmente la mirada del peregrino: “[el tiempo] había movido la superficie del mar y desde luego su mirada de la vida” (123). Ahora verá a través "de su cansada mirada" (125), y todo lo vivido se acumulaba en ella con dolorida señal: "no logró alejar la melancolía de la mirada del aedo peregrino" (136). Para evitar el sufrimiento, el protagonista anhela incluso librarse de todo cuanto la mirada le trae como recuerdo: "su mirada, deslizándose sin rumbo por el dormido mar, parecía buscar la protección del anónimo manto del olvido” (135). Ya en su final, "su cansada mirada avanzaba hacia la oscuridad" (194).

Pero frente a la disolución y el olvido se erige siempre "la mirada interior o la luz de la memoria que retenía la vida” (60), y de la que habló al peregrino su maestro Aristocles. Esa "luz interior de la memoria" (135) brota siempre en la 
mente del peregrino y le trae de forma recurrente los amados momentos de su pasado perdido; y toda nueva vivencia debe buscar de igual modo esa luz: "la luz de los ojos encendidos de Nausícaa tendría que hacerse luz interior [...] poder contener para siempre en su interior la mirada de Nausícaa” (194). Es la luz de la memoria la que le acompaña hasta el último momento: "Casi la única luz que mantenían en su fuego los ojos del aedo peregrino era aquella interior cobijada en la memoria" (198).

Desde otra perspectiva, el mundo exterior también está dotado de mirada, que sale al encuentro de una mirada consciente capaz de percibir su existencia; así el mar: "el mar también tenía tendida su mirada a la espera de otra mirada con la que naciera el camino que transportaba la palabra” (136). O así, sobre todo, las estrellas: "Si tú las miras y ellas te miran tiene que nacer la comunicación" (169). Puede incluso hallarse en ellas las respuestas buscadas; por lo que se invita a su contemplación: "miremos las estrellas. Comprobarás que están muy cerca y leerás en su mirada” (173). Con ellas busca el protagonista un diálogo para saber acerca de sí mismo: "Extendió [...] su mirada por el cielo queriendo adivinar cuál de las estrellas tendría fijado en sus ojos el destino de sus pasos” (169). En especial se establece esa unión con la estrella pequeña y aislada en el cielo que a menudo contempla el peregrino en la novela: "La estrella encendía su mirada intentando encontrar otra mirada con cuya conjugación celebrar la vida” (174). Precisamente observando las estrellas había alcanzado la visión de la armonía del universo ("las contemplaba hasta sentir la admiración por la armonía”, 169); y también una esperanza de eternidad: "Era posible, pensó, que en aquellas miradas nacidas de la contemplación se sostuviera la perennidad luminosa de la vida” (174).

Si la mirada es la vida, en ella se recoge todo lo conocido, percibido o experimentado, y todo ello busca la palabra que pueda nombrarlo, darle existencia.

En torno a la palabra se genera por ello un segundo círculo de reflexión a lo largo de la novela que nos sitúa incluso en el momento primero de la necesidad de expresar: "comprendió [...] que la palabra, antes de ser sonido o de fijarse en letra, podía ser algo que se acunara en el ánimo y allí se formara internamente buscando la armonía que luego fuera expresión” (36) ${ }^{37}$. Ese algo es pura concepción, y también vivencias o emociones: "sentí unas extrañas vibraciones que pedían la palabra” (96). Muy especialmente, es la pasión amorosa: "esa íntima experiencia que el joven peregrino aún no sabía llamar amor era algo que pedía ser expresado" (41). Pero el autor gradúa con sumo cuidado la llegada de ese nombre: "con la palabra ya en vísperas de ser formada" (56). Y por fin la palabra nace "en la mirada de Euriclea”, en la transmisión de su sentir.

${ }^{37}$ El autor expone la idea con palabras semejantes en su conocido ensayo (A. Prieto, 1972): "es hermoso recoger la palabra, acunarla hasta hacerla nuestra y ser en ella, y darle nueva vida para volar en busca de otras vidas”. 
Se suceden aún muy diversos enfoques girando en torno a la palabra, que, ante todo, necesita comunicar, ser acogida o percibida: "Si alguien siente la palabra, la habita en su luz, la palabra está cerca y comparte la intimidad. Pero si ese alguien no tiene la sabiduría de la sensibilidad, ese alguien apaga la luz de la palabra” (170).

A propósito del episodio de las sirenas, alude, asimismo, el autor a la función y el poder de la palabra, “creadora de imágenes”, que estimula la imaginación, frente al poder de la imagen, que nos ciega "anulándose la capacidad de [la] mente para imaginar” (159). Una implícita defensa del arte de la palabra y, por extensión, de las artes verbales.

La defensa se extiende al valor de "la palabra y el ingenio" humanos frente a otras facultades como la "precipitada fuerza", y para el autor-protagonista, que ama la palabra, representa el vínculo con la vida: "Quizás sea lo único que tenga, con lo que mido la vida" (192).

Por otra parte, gracias a la palabra perduran las hazañas ejemplares de los héroes antiguos: "los héroes prosiguen su vida en una isla olímpica que alientan los poetas y perviven en la memoria de las edades. [...] desandar el tiempo [...] es lo que intentan los aedos y rapsodos trayéndonos sus cantos sobre héroes” (51).

Su propio afán de viajar y sufrir experiencias, de "probar la ruta de los héroes" (173), lo es de conocimiento para acumular en su voz, en su conciencia, en la palabra: "tengo que navegar, salir de Quíos y conocer el mundo [...] para que pueda crecer la palabra” (44).

Como sabemos, en su dolorosa peripecia vital, el peregrino no encontró la ruta buscada, pero descubrió en cambio una nueva dimensión humana necesitada de otra voz: "Encontré la palabra, una palabra nueva y más íntima que expresaba al hombre y no al héroe" (173). La misma palabra o conciencia que eleva y hace libre al hombre con un poder superior al de la fuerza: "la palabra podía formarse libremente en cualquier humano y alcanzar con ella el tiempo y el espacio que los héroes no lograban” (97). Gracias a esa voz, unida a la que aprendió oyendo a los aedos, se propone: "escribir de los héroes y con ellos de mí" (97).

La íntima vivencia del hombre vence la distancia del tiempo por medio de la palabra, que es capaz de atestiguar la continuidad ${ }^{38}$ : "la palabra es amplia, puede cobijar sentimientos alejados entre sí por el tiempo y aún buscar con su difícil latido la existencia de unos desconocidos ojos que serán mirada cuando nuestro tiempo sea una arcaica oscuridad” $(116)^{39}$. Al final, para el peregrino es la palabra la

\footnotetext{
${ }^{38}$ La idea venía siendo reiterada en su obra anterior: "Porque solo mi palabra, si lograba acuñarla, tendría aquellos ojos que fueron míos y por los que no se muere en el tiempo” (A. Prieto (1985), p. 76).

39 Es una de las muchas maneras en que el autor define su idea de "fusión mítica", ampliamente expuesta, esta vez atendiendo a la función de la palabra (A. Prieto, 1972): "Se trata de una doble e íntima conjugación temporal que, en su fusión, supone la creación de un
} 
esperanza de unión con Euriclea: "abrazarse en la escondida interioridad de la misma palabra" (208).

Pero la palabra es una forma viva, cambiante, que se renueva y diversifica, que puede ser olvidada y sustituida, lo que dificulta su transmisión: "en aquellos relatos épicos [...] había sonidos que desconocía o que no lograba comprender [...] en el recitado del viejo Aristocles había rasgos jónicos peculiares, en otros aedos escuchaba frecuentes eolismos e incluso voces que pertenecían al arcadio o al chipriota” (35). Tal diversidad, favorecida por el flujo de la transmisión oral, se impone como dificultad para el proyecto que concibe el protagonista: "el joven peregrino intuía ya el difícil reto de la escritura, donde la palabra tendría que fijarse para andar el tiempo y las ciudades sin posibilidad de adecuarse a la variedad de oídos” (35).

En torno a ese gran proyecto se despliega el tercero de los círculos de reflexión, que se inician en la mirada, continúan en la palabra, y generan el propósito de vencer al tiempo fijando ambas en la escritura ${ }^{40}$. Es, en realidad, junto al sentir amoroso, la meta que alienta al peregrino y da sentido a toda su existencia. Desde el principio de la novela, el protagonista concibe su plan como lucha contra la fugacidad de la existencia y la disolución de su memoria; el instrumento eficaz que se le ofrece para vencer ese destino es la escritura y en ella se ejercita durante los primeros años de aprendizaje: "trazando aquellos signos en los que ensayaba contener el movimiento de la realidad, el cual es tan veloz o inexistente que nacimiento y ocaso se confunden en su instante" (50). ${ }^{41}$

En su meditada labor, el peregrino (o nuestro autor) nos hace partícipes de las dificultades del proceso creador: "no bastaba saber el código de la lengua sino que era necesario para entender su significado conocer el código de la vida al que pertenecía” (69). Junto a él asistimos, por encima de todo, al momento fundacional en que la poesía nace como escritura: "Es una lírica interna [...] uno tiene la compañía de la memoria queriendo caminar por el papiro para testimoniar la existencia de los anhelos. Y entonces se buscan las palabras, van naciendo las palabras, con una armonía que contiene la armonía de la cítara y la lira y la doble flauta” (68).

tiempo nuevo, hermosamente acronológico (si es que tiene valor para serlo), que es el tiempo de la palabra" (137).

40 "Escribe la que sin duda se puede calificar como su poética explícita de la ficción narrativa: El ciego de Quíos [...] para glosar ese momento prodigioso en la historia de la literatura en que la palabra oral se hace hexámetros manuscritos y el tiempo de los héroes, la edad de oro, se fija para siempre en la perennidad del arte” (Á. García Galiano (2013), p. 88).

${ }^{41}$ Alude el autor al origen mítico de la escritura: "el prodigioso invento de Theuth” (161), el dios egipcio. 
Para los otros, es difícil comprender la novedosa experiencia: "el sentido de unos extraños signos que se alineaban en hexámetros queriendo fijar en su quietud algo tan rápidamente fugaz como la vida” (135).

Por otra parte, la palabra escrita busca seguir su propio curso: "muchas cosas escribo, que a veces nacen con la misma palabra buscando a sus hermanas" (170). En cambio, los aedos, transmisores orales de la poesía épica, desconocían: "La abierta soledad de la escritura, el quedarse encerrado a solas con la palabra y medirla y pesarla para que la palabra fuera al mismo tiempo cuerpo y espíritu" (166). El protagonista vive la aventura de escribir y presiente la trascendencia de su labor para todos los hombres: "el valor de unos signos que podían retener la mirada fugaz de la vida y esperar que anduvieran los siglos por el encuentro de sucesivas miradas que los existieran” (112). ${ }^{42}$

Fijar en la escritura los relatos de los aedos es su propósito primero, y, con ello, perpetuar en el tiempo la existencia de los héroes de Troya: "hasta que el valeroso Héctor encuentre la palabra que lo nombre en la memoria de los siglos, porque no basta para calmarle el canto oral de los aedos que se pierde en el viento" (64).

Al mismo tiempo descubre que en la escritura se expresa a sí mismo: "la palabra que caminaba por sus hexámetros era al unísono expresión de su ánimo, viviéndose, e instrumento de convivencia humana” (157). Y en ella expresa también cuanto rodea su propia vida: "bien sabía el aedo peregrino que tanto o más que amarse el escritor debía extenderse en decir las cosas que amaba, desde la ciudad a las personas” (130). Más aún, cabe fundir en la escritura la realidad y el sueño: "contener al unísono en la cálida mirada de la escritura la luz de un sueño que tuvo el nombre de Nausícaa y la luz de una vida que llevaba el nombre de Euriclea" (204). Y aún más lejos, crear en la escritura una realidad anhelada: "Feacia había sido el deseado sueño pedido por la intensidad de una vida, que ahora tendría que retener en la escritura el aedo peregrino” (201). Realidad y sueño así alcanzan en virtud de la escritura idéntica existencia: "que Nausícaa permaneciera en el tiempo aunque ni él ni Odiseo, ni siquiera Feacia, existieran. Pero sí, sonrió, todo existía y podría ser diversamente existido por la mirada sucesiva de los mortales” (196).

De tal modo, la escritura se convierte en el espacio de la existencia verdadera: "sabía el aedo peregrino que su tierra, su única tierra era la escritura" (200). Al final se convierte en el último refugio: "Se arropaba así el aedo peregrino contra el frío de la soledad y amaba la compañía de la medida palabra” (207).

\footnotetext{
${ }^{42}$ La atemporalidad de la "fusión mítica" se proyecta aquí en el punto de partida, como una esperanza de futuro. Lo había anticipado el autor años atrás: "Estas palabras que escribo ahora [...] su única esperanza es que otros ojos, al leerlas, las vivan, les den generosamente parte de su vida (y esas palabras que fueron tiempo mío amarán los ojos que las leen porque son de ellos, de su tiempo y vida)” (A. Prieto (1972), p. 154).
} 
Mucho antes, ha dejado en libertad su obra escrita para salir en busca de la imaginación de otros hombres: "que la escritura buscara por sí misma las miradas y los oídos que la existieran” (173). E imagina el momento a través de los siglos en que su obra encuentre el lector que de nuevo la convierta en vida, que la recree: "la mirada de sus hexámetros esperando la mirada de unos ojos lectores de cuyo encuentro brotara la luz de la existencia” (129).

En esa transmisión, la escritura alcanza un fin moral como enseñanza de modelos para los hombres: "los dioses le habían concedido el don de la escritura para que sus hexámetros guiasen un tanto a los mortales" (145). En su sentido trascendente, con la palabra escrita se aproxima el hombre a los dioses en su afán de perdurar: "a los dioses no les alcanzaba la oscuridad de la muerte, pero carecían, en cambio, del don de la palabra escrita" (95). Incluso se siente el peregrino semejante a los dioses, como dueño de los personajes que ha creado: "Por qué no iba él a poder cambiar el destino de los héroes que le llegaban en la voz de los aedos, si él poseía el tiempo en el espacio de la escritura al igual que los dioses poseían el tiempo y extensión de los mortales” (95).

Una larga y compleja meditación vierte nuestro autor en su novela acerca del inmenso proceso que se inicia en la conciencia, se transforma en palabra transmisible y se perpetúa en la escritura: "recitaba las navegaciones de un hombre nuevo, que deseaba mirar a Occidente y al que iba dejando en sus hexámetros para encontrar la mirada de los tiempos” (207). El proceso es, nada menos, que el punto de partida de la civilización.

\section{Las emociones sensoriales}

Del alto vuelo intelectual que recorre la novela se desciende a menudo para posarnos en las realidades sensoriales, alcanzando así la amplitud de la vida. Todos los sentidos del autor se despiertan al servicio de su fina percepción y se vierten en las vivencias del peregrino. Al mismo tiempo, ese plano sensorial nos lleva a evocar sin cesar el universo de la cultura mediterránea, la cultura clásica, la cultura en torno a un $\operatorname{mar}^{43}$.

Toda la experiencia del peregrino se despliega "siempre frente al mar" (33) desde la isla de sus orígenes, Quíos, a la isla de su destino, Íos, pasando por Feacia, la isla soñada, y pasando por algunos otros breves escenarios de su azarosa vida.

\footnotetext{
43 "El mar sirve de gozne para introducir el mito, y ello es posible porque el mar estaba presente [...] en toda la producción de Prieto, con una fuerza capital, y había sido también el escenario de tantos y tantos episodios míticos del mundo clásico evocados por el autor” (M. Hernández Esteban (2005), p. 82)

44 “Mar es la gran palabra para Prieto, significa plenitud, eternidad, ausencia de la muerte, aglutinador del tiempo y la memoria” (A. Casado (1997), p. 123).

"En multitud de pasajes el autor aguileño nos hace sentir las vibraciones marineras sin utilizar los campos semánticos que rodean a la palabra mar. Y ahí está uno de los méritos de
} 
Algún estado emocional impregna casi siempre las sensaciones del protagonista, incluso en la más elemental: "el buen sabor que iba dejándole en la boca el queso ofrecido" (62). Lo recibe de Paleneo en el comienzo de su amistad, y le hace recordar el ofrecido por su previsora madre.

Los aromas se cubren de poder evocador, como el del fuego encendido por una ninfa "con los troncos del cedro y del alerce" (137). O, más cercano al juego de la memoria proustiana, como esta sinestesia: "Le llegaba el fuerte olor de los limoneros de Quíos cuando se colgaba en la primavera de Euriclea transformando su cuerpo en el blanco movimiento del azahar" (136). Poco más que un aroma sirve para crear la imagen de la amada: "se aproximó tanto que pudo oler en su piel el perfume salvaje del mar” (60). De forma recurrente, por ese perfume será evocada siempre en la novela, incluso cuando es confundida con Eurícide (148), o cuando renace en Nausícaa: "Estaba seguro de que si se acercaba a ella sentiría el perfume salvaje del mar en su cuerpo" (185). Y apenas con otra sensación, reiterada también, se completa siempre la imagen de la joven: "sus bellas mejillas, que tenían el ligero temblor de la brisa" $(60,125$, etc.).

Los contactos nos transmiten otro caudal de sensaciones por las que el lector puede recordar, por ejemplo, el tacto de la arena: "Euriclea y sus amigas, con los pies descalzos, corrían por la arena jugando a la pelota" (37). O sentir la huella física del tiempo en el peregrino: "salpicado por el sol y la sal de los mares" (133). $\mathrm{O}$ percibir el placentero contacto del aire que le envuelve a veces: "sintió en su rostro la embrisada caricia de la ciudad” (166). Un placer propiciado a menudo por la noche, impregnándolo todo: "la mesurada beatitud de una noche que iba depositando el relente sobre los árboles cercanos” (167). En forma metafórica, la noche es un tacto que conduce al sueño: "la calmada noche depositaba en sus párpados los suaves dedos” (106).

Los contactos son, como es lógico, expresión del erotismo. En un plano puramente físico se alude a la relación de Paleneo con su amante: “llegó [...] con su cuerpo bañado en el olor de la complaciente Praxila” (72). En cambio, la relación erótica del peregrino es fruto siempre de su intenso sentir amoroso, aunque, siendo muy joven, había experimentado el puro deseo. En el plano real, el protagonista siempre renuncia al trato con las hetairas que le propone Paleneo, por amor a Euriclea, para compartir solo con ella "la espléndida trayectoria del amor" (66). Una trayectoria que sigue siempre un curso imaginario, a veces incluso a gran distancia, como la contemplación simultánea del cielo por los dos amantes: “y así poder abrazarse en el silencio nocturno marcado por las estrellas" (71). A menudo imagina el personaje el placer de la proximidad, su deseo de contacto, siempre imaginario. Es real el beso en el rostro recibido de Eurícide, aunque sentida como

este ilustre narrador: hacernos intuir con sutiles imágenes y sentimientos la inapreciable presencia del mar” (F.J. Montalbán (1990), p. 155). 
Euriclea regresada: "para sembrar fuertemente sus labios en su piel arañada por los vientos" (150). Y entre la realidad y la ficción, como todo en el episodio de Feacia, se alcanza el beso con Nausícaa: "ambos sintieron en común el mismo encendido latido.” (190). Igual sucede con el anhelo de encuentro amoroso, a escondidas de los padres, sugerido por el ejemplo de Zeus y Hera (80), que parece ser recordado más tarde como un hecho real vivido con Euriclea en el pasado: "cuando sus ojos [...] expresaron que podían amar y fueron luego intenso amor a escondidas de sus padres” (183). Y vivido como real, aunque dentro de una realidad soñada, culmina el amor entre el peregrino-Odiseo y Euriclea-Nausícaa: "cumplieron armoniosamente con el vaticinio de la risueña y dorada Afrodita, nacida de la espuma del mar" (193).

Las escenas se envuelven siempre en placenteros sonidos: "En la playa, las olas recitaban suavemente su llegada" (56). Algunas veces, su ritmo enciende el recuerdo: "escuchando el sonido de los acompasados remos hendiendo el mar" (199). Otras, es un anhelo "escuchar el susurro marino del viento" (203). Y otras es un recuerdo: "el mar dejaba que las olas pasearan la arena sin apenas sonido para no despertarse" (179).

Ese tenue rumor, que sucede un amanecer, se pierde otras veces en el silencio: "Creció luego en ellos el silencio, acompasado por el ligero mar" (44). Es en la noche cuando triunfa el silencio: "Tenía la noche la hermosa ornamentación del silencio" (170). Aunque también reina en la tarde formando un bello juego de sinestesia con el color y el movimiento: "Proclamaba la tarde de Íos su silencio, y era un hermoso silencio en el que parecían navegar las gaviotas blanqueando el azul y al que musicalizaban los delfines arqueando su cuerpo sobre el mar” (204).

Muy pocos sonidos, apenas unas "chillonas cornejas" (137) cruzan la apacible naturaleza. Y dando la palabra a todo el relato suena de fondo la voz "virilmente armoniosa” (114) del peregrino.

Como es natural, la luz es fuente de muy bellas percepciones enmarcando las vivencias del personaje, o alimentando sus recuerdos; y al mismo tiempo, la luz señala los momentos del día, de modo que nos acerca a los tonos de los relatos homéricos. Así, la hermosura de Euriclea se compara con "los rosados amaneceres que bañaban su luz en el Egeo" (106), y los lectores evocamos a la mitológica "Eos, de rosados dedos, hija de la mañana". Así, la memoria del peregrino intenta "recrear aquellos serenos amaneceres de Quíos" (179) ${ }^{45}$.

Elevado el sol en su órbita, la luz alcanza la plenitud del color: "El sol doraba intensamente las cansadas aguas del Egeo” (32). En su primera visión de Euriclea, el peregrino "tuvo la impresión de que la transparencia de luces [...] modelaba su figura” (36). Y también en su memoria la luz y el mar se funden en una visión

\footnotetext{
45 "La influencia estilística del viejo lenguaje épico se plasma también [...] en algunos amaneceres mitológicos que marcan el tiempo de la novela” (V. Cristóbal (2005), p. 334).
} 
anhelada: "flotar por un mar calmo que de día era intensamente azul, con un azul bañado por el sol que ningún otro mar poseía” (83).

Las luces se van matizando con la tarde e impregnándose de emociones: "llegaba la serenidad de la tarde, con el mar olvidado de sus ímpetus" (48); o mezclándose con otras sensaciones en una sinestesia: "el cálido sol doraba la tarde de serenidad y las olas se desperezaban suavemente sobre la arena" (40). Y en su contemplación, el peregrino alcanza la plenitud: "veía el mar [...] y admiraba el intenso azul que vestía agradeciendo la luz de las tardes serenas” (205).

Siguiendo su curso, el sol declina y transforma de nuevo la realidad: "El sol iba apagando su cálido color sobre las islas, rezagándose en su paso por el mar” (102); "perdiéndose ya el color de la tarde hacia las grises sombras" (43). Y para cerrar el curso de la luz otra imagen poética lo culmina: "Apretó la noche sus dedos oscuros sobre Imbros" (76).

Aunque dispersas a lo largo de la novela, las referencias aquí agrupadas revelan el orden profundo que las une, y que nace en la muy sensible percepción del autor y se expresa en contenido lirismo, venciendo definitivamente: "a ese viento que borraba la voz para llevarla al silencio que ocupaban los siglos” (29).

\section{Las modulaciones de la voz. Un universo en rotación}

Regresando ya de nuestro recorrido por la novela, aún hemos de aludir a otro ancho caudal que fluye dentro de ella: la recreación de la antigüedad griega que llamamos homérica. No flotan en un tiempo/espacio vacío la vida del peregrino y su larga meditación, sino insertas en un mundo coherentemente construido, en espacios geográficos y procesos históricos conocidos, reproduciendo sus usos sociales y sus formas culturales con sus mitos y creencias. Como ya mencionamos, todo ello procedente del saber humanista de Antonio Prieto. Reunamos al menos unas líneas esbozadas de ese mundo recreado.

Muchas son las islas del Egeo visitadas a lo largo del relato (Lemnos, Imbros, Corcira...), muchas más son aludidas (Esciros, Cos, Delos...) y alguna, como sabemos, es imaginada (Feacia); todas ellas de sonoro topónimo, al igual que los montes divisados (Mícala, Atáviro, Pandokráteras...) y los ríos (Meandro, Hebro, Caístro...), y las ciudades visitadas o recordadas (Yáliso, Pilos, Náucratis...).

Muchos son los pueblos aludidos, no solo troyanos o dárdanos y aqueos o dánaos, sino los licios, los lidios, los invasores dorios o los lejanos cimerios. Y sabemos del auge de los jonios y de la decadencia de los fenicios en el comercio con Oriente en torno al tiempo homérico; y de las invasiones aqueas y dorias; y de dinastías, reyes y héroes legendarios.

Dentro de ese marco, el autor nos conduce por la vida cotidiana de aquella sociedad valiéndose de los conocimientos arqueológicos y literarios. Entramos así en el hogar (oikos, 89), donde arde el fuego y se rinde homenaje a los antepasados (37), donde la mujer hila y teje (117), las sirvientas muelen "las harinas de trigo y cebada para el pan” (127) y el hombre ejerce la "necesaria autoridad” (37). Visten 
túnicas, mantos y "peplos de fina labor” (187), y peinan "trenzados cabellos” (183). Y los guerreros legendarios, con "broncíneas túnicas" (87), o con "corazas y túnicas de lino", se cubren con "cascos con penacho de crin de caballo" y ciñen "espadas de Cálcide y grebas” (70), o los “ornamentados escudos” (48) de los hoplitas.

Los pobres se alimentan de queso, habas, cebollas, miel, o "tortas de cebada y pescado fresco" (62). Y en el banquete palaciego, "de pan, carne y espumoso vino certeramente mezclado en la crátera" (175). Asistimos a los rituales de la hospitalidad: el saludo y el convite ("como en los tiempos venerables se hacía", 188). Con deleite es descrito el ritual del baño atendido por "dos sirvientas de ágiles manos" (145-146).

Se alude a la organización laboral, ganadera y artesana de "las ciudades eubeas o tesalias" (117); o a la labor de los ceramistas de Atenas (31); o a la evolución de las vasijas cretenses y micénicas hacia formas geométricas, y a su exportación por las rutas comerciales (53); o a la cerámica roja y las acróteras de Corinto (67); o al valor otorgado al cobre para fabricar objetos prácticos y ornamentales (91). Y se ofrece un retablo de la vida ciudadana en la isla de Lesbos (70).

Sabemos de la navegación por los mares y de "la corva nave" (59), o del "combo bajel" (157), de "cincuenta remeros", hecho de "madera de abeto, y su quilla de fresno" (47); y nos envuelve la vida marina con el léxico preciso: junto a la vela, el mástil o la verga, las "regalas” (84) o las “drizas” (91), o "los calafates” (69) que embrean el casco.

Se mencionan las fiestas sagradas "donde se cultivaba la música [...] los ejercicios corporales" y los artistas se inspiraban en "el desnudo" (56). O los "hogares [...] servidores de las musas", dedicados a la música, a la belleza y a "los himnos en honor de Afrodita y de Eros", que eran "herencia de los tíasos" (110) O también, "los agones o concursos" donde se recitan "partenios en honor de las doncellas", "ditirambos, en honor de Dionisio", o se cantan "monodios" con la lira o la "cítara” (67).

Conocemos, asimismo, los rituales funerarios: como "el óbolo" entre los dientes, para pagar el "pasaje a Caronte" (37); o las honras fúnebres y celebraciones dedicadas al difunto según su rango (82-83); o las muestras de dolor, cubriéndose la cabeza de ceniza junto al coro de plañideras, como Aquiles por Patroclo; o el humilde ritual dedicado por el peregrino a Paleneo, descrito por omisiones (117118).

Buscan augurios que desvelen su destino, a veces recurriendo a juegos como "el cótalo" (70); otras, acudiendo a la ayuda de un adivino (131-133). Dioses y mitos conducen su vida o les sirven de ejemplo; en consecuencia, son muchas las escenas y los episodios mitológicos insertos en la novela, pero siempre muy escogidos, o mejor, poco habituales en las representaciones artísticas: como el juego amoroso

\footnotetext{
${ }^{46}$ Hermandades o cofradías encargadas de las celebraciones en honor de una divinidad.
} 
entre Zeus y Hera, a escondidas de sus padres (79); o los amores de Zeus y Alcmena, alterando el curso de los días (55); o los de Selene y Endimión; o los vientos y astros engendrados por Aurora y Astreo (91); y no solo nos habla de náyades, sino de "dríades” o "hamadríades” ligadas a un árbol (181).

Como es natural, se recrea en la novela todo lo conocido en torno a aedos y rapsodos, desde sus pocos nombres conocidos, como "Támiris y Demódoco" (144), Cineto (65), o Eumelo de Corinto (67); o los espacios habituales de sus recitados, "las cortes", "los festivales religiosos", "los concursos" o "los funerales" (39); o algunas claves de su versificación, como la repetición del mismo epíteto para un sustantivo, útil en su arte de improvisar (38).

Al servicio de todo este universo se disponen las modulaciones de la voz haciéndolo girar. Son numerosos los elementos técnicos de la novela ya aludidos al desvelar su composición (ver apdo. 3), entre ellos, la posición del narrador, la condensación de las descripciones y de la acción narrada, concentrada en escasos momentos reiterados y recortada por la gran elipsis, o la concisión de los diálogos y la sobriedad que tiñe todo el lenguaje, incluso en los momentos de lirismo o en los de intensa emoción (como la del regreso a Quíos tras largos años: “Su isla”).

La amplitud y riqueza del léxico en distintos niveles, viene a ensanchar los límites del relato, según hemos visto. Es riguroso y preciso para ilustrar las referencias históricas y culturales: topónimos, gentilicios o términos como "aristía" (112), “asfódelos” (136), “pentecónteras” (47), “exarconte”, “diolcos” (67), "wánax" (35). Y lo es en las incontables alusiones mitológicas. Un léxico siempre culto, nunca coloquial, que fluye con naturalidad de sabor clásico, y que se envuelve en lirismo para expresar lo sensorial o emotivo. De todo ello hemos visto abundantes muestras, pero ¿cómo se crea el lirismo ${ }^{47}$ Nunca por retoricismo o acumulación de imágenes, sino por la intensidad del concepto, incluso por ciertos juegos conceptistas, como apagar la oscuridad: "antorchas que apagarían con su ardor la oscuridad de la noche” (187). O por un juego de conceptos y sinestesia a la vez: "su aire tenía un sabor de distancia" (126). O el juego entre el epíteto de Aquiles y su cólera, determinante del argumento de la Ilíada: "los pies ligeros de Aquiles, calzados en su cólera” (39).

Muy especial valor poético conceptual alcanza el verbo existir, estático, dinamizado como un transitivo: "otra mirada que [...] la existiera" (194); incluso construido en la perífrasis "poder ser existido” (196).

$\mathrm{Y}$ a veces, lo poético se funda en una referencia literaria, como en "se hizo la sonrisa en su rostro" (183), que evoca el bíblico "se hizo la luz"; o como "la mirada de Nausícaa habitó en el aedo” (184), del también bíblico "habitó entre nosotros”. Y

47 “Se aprecia que cada término, cada verbo, nombre o adjetivo está medido en el pensamiento para buscar la musicalidad de la palabra” (N. Algaba (2005), p. 389). 
machadiano es sin duda: "Late, corazón, que no todo está hundido" $(135)^{48}$. Son siempre alusiones con que el autor alimenta estados emotivos.

Como es natural, la novela se contagia sobre todo del lenguaje homérico, rindiéndole homenaje al mismo tiempo. Algunos son rasgos constantes, como la anteposición frecuente de los adjetivos, o el uso de epítetos épicos para los personajes (“de ojos encendidos”, “de agrietada voz”). Otros rasgos, más ocasionales, son de orden sintáctico y rítmico. Nos sorprende el tono ceremonial de frases como: "quebró Lárico el denso silencio" (118), o como "Ve, extranjero, a tus mares" $(197)^{49}$.

Pero son a menudo las transiciones narrativas las que nos recuerdan el relato homérico. Con tal función irrumpen los vientos: "Con el viento del sur animando la purpúrea vela arribó la corva nave” (69). O se señala el transcurso del tiempo: "En el nuevo día" (74); "La enamoradiza Aurora [...] se levantó" (91); "El sol había huido de la tarde" (75); "La Noche [...] desplegó sus oscuras y ligeras alas” (89). En alguna ocasión se alcanza incluso un tono épico: "Quizás Posidón [...] se cargó de ira y levantó furiosos vientos que se enzarzaron con las olas del ancho mar produciéndose estrepitoso sonido" (157).

Y más allá, alcanza a veces el autor un ritmo cercano al hexámetro homérico: "Creció luego en ellos el silencio, acompasado por el ligero mar" (44); "Vertió entonces Atenea el sueño en sus ojos” (183); “en una lóbrega noche que cercaba las naves con su densa sombra" (141); "Fue entonces cuando el magnánimo rey, señalando la lira sonora” (195). Sirvan estos ejemplos, junto a los muchos ya recogidos hasta aquí, y evitemos la acumulación innecesaria. De todos ellos ha nacido el deleite del atento lector durante su recorrido por la novela.

\section{El encuentro en la escritura}

Ya de regreso, nos sentimos partícipes del diálogo entablado por Antonio Prieto con el lejano tiempo de las epopeyas homéricas. Los fragmentos del mapa al que aludíamos al principio han cobrado forma y sentido, y el autor ha logrado completarlo incorporando su presente, su pensar y su sentir, reuniendo los tiempos, creando una corriente de vida y asegurando su permanencia. ${ }^{50}$

${ }^{48}$ En el Poema CXX de Campos de Castilla, dice Machado: “Late, corazón... No todo se lo ha tragado la tierra”. Precisamente estos versos son citados por el autor al final de su ensayo sobre la fusión mítica (A. Prieto, 1972).

49 "Prieto personaliza las palabras que toma de esos autores a los que admira, de esa tradición que mantiene viva, [...] las citas de los clásicos; a menudo se empeña en renacerlas con un sentido propio en el tejido narrativo de sus novelas” (N. Algaba (2005), p. 375).

50 “No se trata en rigor de una novela histórica [...], sino de una novela cultural, de muy alto vuelo literario e incluso de continuada palpitación poemática” (C. Clementson, 1996). Y de 
En su novela nos ha llevado de la referencia erudita, escondida en el relato, sustentándolo, a la vivencia emotiva imaginada y a la abstracción de elevar la vida al mundo ideal. Nos ha llevado por la historia, por la literatura, por la mitología, y por el interior de sí mismo, y con ello nos ha guiado en busca de nosotros mismos ${ }^{51}$.

Recordemos que los motivos esenciales de la novela se reiteran dejando espacios para la amplia información documental y dando anclaje a la incesante reflexión. Y al mismo tiempo generan un ritmo musical en su estructura, como melodías que ocupan el sonido de fondo de una sinfonía, y que sostienen y anudan el fluir de las otras notas.

La potencia creadora de esta novela reside en la difícil y habilísima fusión entre una conciencia de hoy, dueña de sí misma, anhelante de algo más, y el inmenso caudal de conocimiento que la desborda. Más que de una autobiografía interior se podría hablar de una novela que se autoinventa en el mundo ideal de la literatura ${ }^{52}$. El pasado histórico y literario, la imaginación, las ideas, una constelación gravitando dentro del relato en torno a la única y verdadera voz, la de su autor Antonio Prieto. Una voz que no es terciopelo o seda; por su sobriedad y exquisitez, su palabra sugiere siempre el tacto de fino, blanco y fresco lino.

En un plano vital, con su mirada y su palabra, nos sentimos viviendo por atardeceres o amaneceres, o por el pleno día de las islas del Egeo. Y al leer esos versos homéricos que cierran la novela ("Musa, dime del hábil varón....”), nuestra memoria lectora se abisma hacia un tiempo lejano en que sentimos por primera vez la emoción y la expectación que nos causaban esas “aladas” palabras. Y así como el visitante de la cabaña recibe el mundo homérico a través de la voz de Ifigenia, nosotros lectores recuperamos ese mundo anchamente con la mirada de Antonio Prieto.

Triunfa en ella el idealismo; incluso, según hemos visto, el autor rinde tributo al Platonismo, expreso en todo el orden de la novela. Pero parece ser fruto de la insatisfacción de la realidad, del mismo anhelo que sentiría un romántico empujándole en su huida hacia el pasado. Aunque hay una gran diferencia, es una huida planificada y documentada, como la organizaría un científico, en este caso, con el conocimiento de un humanista. Y solo este doble impulso hace posible su novela.

novela intelectual la juzga Alvar (1996 a): "digamos, novela intelectual, marcada por unos sentimientos que Petrarca nos legó a los hombres que tras él hemos vivido”.

51 "Un homenaje a la invención de la palabra escrita, al legado imperecedero de la tradición clásica y un resumen de las más hondas e íntimas convicciones literarias y vitales de su autor” (Á. García Galiano (2004), p. 83).

52 "La novela de Antonio Prieto es una criatura del arte” (M. Alvar, 1996 c). "La novela de Prieto no es la afortunada recreación de una serie de mitos: es la encarnación del hombre en cuanto más noble existe en la naturaleza” (M. Alvar, 1996 a). 
¿Es novela de fusión mítica, fiel al modelo definido años antes por su autor? ¿Es novela histórica, o cultural, o poemática, o intelectual, según han juzgado distintos estudiosos? ¿Es novela humanista, o mítica; o es novela sentimental, o intimista, o vitalista, o es, sobre todo, una novela existencialista? Sí, lo es. Al lector se ofrece como todas ellas a un mismo tiempo.

Novela en que el dolor, rehuido como suceso real, late sin cesar en el fluir del relato, como un trasfondo ineludible. Una novela de amor, al hombre, a la literatura, a la historia, a la belleza, a la mujer; transida de amor a todo lo mejor del ser humano.

En realidad, nos ha hecho partícipes de la larga reflexión en torno a los asuntos que conciernen a los hombres de todos los tiempos y que les han de pertenecer siempre: el amor, la muerte, las metas vitales, los anhelos de plenitud, el ansia de permanecer.

Por todo ello, el autor ha movido la historia remota, la literatura primigenia, los mitos que nos han alimentado, el alto y noble lenguaje, cuidado y escogido, de la inteligencia lúcida y de la dignidad defendida, y ha movido nuestras emociones confundiéndolas con las de dioses, héroes y sobre todo con ese alter ego suyo que es su peregrino, y las moverá siempre, porque también él ha hallado la palabra escrita para vencer y traspasar el tiempo, los tiempos ${ }^{53}$.

Cesa la lectura, reposa la escritura a la espera de la nueva mirada que la haga vida, que la "exista”, diría Antonio Prieto.

\section{Obras citadas}

ALGABA, Nieves (2005): "La última narrativa de Antonio Prieto o las distintas formas de vencer el tiempo", Antonio Prieto en su texto total, vol. I, G. Garrote Bernal (Coord.), Biblioteca de la Universidad de Málaga, 2 vols., pp. 345-399.

ALVAR, Manuel (1996 a): “¿Novela?”, Blanco y Negro (16-6-1996). (1996 b): "El nombre hace al hombre”, Blanco y Negro (23-6-1996). (1996 c): “No importa la precisión de los años”, Blanco y Negro (306-1996).

CASAdo Vegas, Alicia (1997): "Las correcciones en la novela de Antonio Prieto", Dicenda, $\mathrm{n}^{\circ}$ 15, Madrid, Universidad Complutense, pp. 117-142.

Clementson, Carlos (1996): "Una novela sobre Homero (El ciego de Quíos)", Diario de Córdoba, Cuadernos del Sur (9-5-1996).

\footnotetext{
53 “Tal vez, ese empeño por legar a otros, los futuros lectores, algo resonante, perdurando más allá de la ceguera y la vejez y la muerte es el impulso que siente todo auténtico escritor, novelista o poeta” (C. García Gual, 2010).
} 
COLÓN CALDERÓN, Isabel (2008): “Cortés lisonja a los sentidos: olor y tiempo en Isla blanca y Reliquias de la llama de Antonio Prieto", en Humanismo y pervivencia del mundo clásico: homenaje al profesor Antonio Prieto, Vol. IV, José María Maestre Maestre, Joaquín Pascual Barea, Luis Charlo Brea (coords.), Madrid, Consejo Superior de Investigaciones Científicas, pp. 577586.

CRISTÓBAL LÓPEZ, Vicente (2005): “El ciego de Quíos, respuesta ficcional a la cuestión homérica”, Antonio Prieto en su texto total, Ob. cit., 325-343.

GARCÍA GALIANO, Ángel (1996): "La obra narrativa de Antonio Prieto entre 1955 y 1975”, Antonio Prieto en su texto total, Ob. cit., pp. 111-177. (1996): “El ciego de Quíos”, Madrid, Cuadernos de Filología Clásica, $\mathrm{n}^{\circ}$ 6, Universidad Complutense, pp. 327-330.

(2004): El fin de la sospecha. Calas significativas en la narrativa española, 1993-2003, Universidad de Málaga. (2013): "El fuego secreto de Quíos”, El fuego sordo. Lecciones de Literatura Contemporánea, Madrid, Ed. Xorki, pp. 55-92.

García GuAL, Carlos (2008): "Evocaciones homéricas en El ciego de Quíos", Humanismo y pervivencia del mundo clásico: homenaje al profesor Antonio Prieto, Ob. cit., pp. 545-553.

GARROTE BERNAL, Gaspar (2005): “Compartiendo existencias: La novela histórica de fusión mítica”, Antonio Prieto en su texto total, Ob. cit., pp. 245-285.

GÓMEZ RAMOS, Emiliano (1997): Literatura culta y popular en Andalucía, III Simposio, Almería.

GoNZÁLEZ, Juan Manuel (1999): “Antonio Prieto: cómo narrar desde la tradición clásica”, El viento entre los juncos. Libros y autores para el cambio de siglo. Madrid: Sial Ediciones, pp. 197-198.

HERnÁNDEZ EsteBAn, María (2002): "La fusión mítica en la teoría crítica de Antonio Prieto”, El mito, los mitos, Alvar, C. (Coord.), Madrid, Sociedad Española de Literatura General y Comparada, Caballo Griego para la Poesía.

(2005): "El mundo mítico en la narrativa de Antonio Prieto", Antonio Prieto en su texto total, Ob. cit., pp. 63-110.

HERNÁNDEZ, Teresa (1996): "Voz que no se apaga”, Diario 16 (16-3-1996).

HERNÁNDEZ, Ramón (1996): “En la mirada de Ifigenia”, La Esfera (30-3-1996).

LÓPEZ LÓPEZ, Mariano (1992): “Análisis formal y temático de la obra narrativa de Antonio Prieto”, El mito en cinco escritores de posguerra, Madrid, Ed. Verbum, pp. 343-368.

MontAlBÁN Rodríguez, Francisco José (1990): "El mar en la obra de Antonio Prieto”, Anales de Filología Hispánica, Vol. 5, Universidad de Murcia, pp. 155-166. 
PALOMO VÁzQUEZ, Ma del Pilar (1967): "La novela española en lengua castellana (1939-1965)”, Historia General de las Literaturas hispánicas, vol. VI, Barcelona, Ed. Vergara, pp. 697-733.

PRIETO, Antonio (1972): "La fusión Mítica”, Ensayo semiológico de sistemas literarios. Barcelona: Ensayos/Planeta (Dirección Antonio Prieto y Ángel Valbuena Prat), pp. 135-187.

(1985): “De mi voz en Nausícaa”, Texticulario andaluz (Antología de prosa no integrada), Antonio Zoido y Michel Marie Marchand (Eds.), Córdoba, Editorial El Almendro, pp. 71-78.

(1996): El ciego de Quíos, Madrid, Ed. Seix Barral.

SUÁREZ DE LA TORRE, Emilio (2008): "La mirada de Ulises: el Mundo Antiguo en la narrativa de Antonio Prieto", Humanismo y pervivencia del mundo clásico: homenaje al profesor Antonio Prieto. IV, Ob. cit., pp. 555-575. 